INTERNATIONAL FOOD

POLICY RESEARCH INSTITUTE

sustainable solutions for ending hunger and poverty

IFPRI ${ }^{\circledR} \quad$ Supported by the CGIAR

IFPRI Discussion Paper 01017

August 2010

\title{
Analyzing Nutritional Impacts of Policies \\ An Empirical Study for Malawi
}

\author{
Olivier Ecker
}

Matin Qaim

Development Strategy and Governance Division 


\section{INTERNATIONAL FOOD POLICY RESEARCH INSTITUTE}

The International Food Policy Research Institute (IFPRI) was established in 1975. IFPRI is one of 15 agricultural research centers that receive principal funding from governments, private foundations, and international and regional organizations, most of which are members of the Consultative Group on International Agricultural Research (CGIAR).

\section{PARTNERS AND CONTRIBUTORS}

IFPRI gratefully acknowledges the generous unrestricted funding from Australia, Canada, China, Denmark, Finland, France, Germany, India, Ireland, Italy, Japan, the Netherlands, Norway, the Philippines, South Africa, Sweden, Switzerland, the United Kingdom, the United States, and the World Bank.

\section{AUTHORS}

Olivier Ecker, International Food Policy Research Institute

Visiting Postdoctoral Fellow, Development Strategy and Governance Division

O.Ecker@cgiar.org

Matin Qaim, Georg-August University Goettingen

Professor, Department of Agricultural and Rural Development

\footnotetext{
Notices

${ }^{1}$ Effective January 2007, the Discussion Paper series within each division and the Director General's Office of IFPRI were merged into one IFPRI-wide Discussion Paper series. The new series begins with number 00689, reflecting the prior publication of 688 discussion papers within the dispersed series. The earlier series are available on IFPRI's website at http://www.ifpri.org/publications/results/taxonomy\%3A468.

2 IFPRI Discussion Papers contain preliminary material and research results. They have been peer reviewed, but have not been subject to a formal external review via IFPRI's Publications Review Committee. They are circulated in order to stimulate discussion and critical comment; any opinions expressed are those of the author(s) and do not necessarily reflect the policies or opinions of IFPRI.
}

Copyright 2010 International Food Policy Research Institute. All rights reserved. Sections of this material may be reproduced for personal and not-for-profit use without the express written permission of but with acknowledgment to IFPRI. To reproduce the material contained herein for profit or commercial use requires express written permission. To obtain permission, contact the Communications Division at ifpri-copyright@cgiar.org. 


\section{Contents}

Abstract $\quad$ V

1. Introduction 1

2. Data and the Nutritional Assessment Approach 3

3. Food and Nutrient Consumption and Deficiencies 5

4. Methodology for Elasticity Estimation $\quad 8$

5. Income and Price Effects on Food Demand and Nutrient Consumption 13

6. Policy Simulations 17

7. Discussion and Conclusion 19

Appendix: Supplementary Tables $\quad 21$

$\begin{array}{ll}\text { References } & 28\end{array}$ 


\section{List of Tables}

1. Food and nutrient consumption and prevalence of nutritional deficiencies 5

2. Correlations of key nutrition and economic indicators among rural and urban households 7

3. Expenditure and Marshallian own-price elasticities of food demand among rural and urban households at population means and for the poorest and richest quintiles

4. Nutrient elasticities with respect to household expenditure and food prices in rural areas $\quad 14$

5. Nutrient elasticities with respect to household expenditure and food prices in urban areas $\quad 15$

6. Simulation results for household income and maize price changes by 20 percent 18

A.1. Summary statistics of income- and price-related variables in the demand models for rural households

A.2. Summary statistics of income- and price-related variables in the demand models for urban households

A.3. Estimation results of the Working-Leser models for rural and urban households

A.4. Estimation results of the QUAIDS models at the second and third budgeting stage for rural household

A.5. Estimation results of the QUAIDS models at the second and third budgeting stage for urban household 


\begin{abstract}
Widespread malnutrition in developing countries calls for appropriate strategies, presupposing good knowledge about nutritional impacts of policies. Little previous work has been carried out in this direction, especially with respect to micronutrients. We use representative household data from Malawi and develop a demand systems approach to estimate income and price elasticities of food demand and nutrient consumption. These estimates are applied for policy simulations. Given multiple nutritional deficiencies, income-related policies are better suited than price policies to improve nutrition. Although consumer price subsidies for maize improve calorie and mineral consumption, they can worsen vitamin consumption in urban areas.
\end{abstract}

Keywords: quadratic almost ideal demand system, micronutrient deficiency, income and price elasticities, nutrient consumption, Sub-Saharan Africa, Malawi 



\section{INTRODUCTION}

The 2007-2008 food price crisis and the following global economic recession have pushed the number of hungry to historic levels, exceeding one billion people worldwide (FAO/WFP 2009). However, the number of hungry marks only the peak of the malnutrition problem. Though less obvious, micronutrient deficiencies - mostly caused by insufficient intake of food rich in bioavailable minerals and vitaminsare even more widespread (Mason, Rivers, and Helwig 2005). The risk of micronutrient malnutrition has increased significantly in the course of the recent crises (Brinkman et al. 2009). Resulting health problems may involve serious long-lasting consequences for individual well-being and economic growth (Horton and Ross 2003; World Bank 2006).

Recognizing the threats for development, policymakers are concerned about sound strategies to improve people's food security and reduce adverse nutritional impacts of future crises. Yet the debate is often limited to food availability and accessibility in terms of calories, neglecting the important role of micronutrients. Clearly, broader nutritional policies require better knowledge about people's food and nutrient consumption patterns and responses to changes in household income and food prices. Food demand analysis offers an important tool in this regard. Income and price elasticities measure the percentage change in food consumption from a 1 percent change in income and prices. Traditional food demand models, which primarily look at food quantities consumed, can be extended to model the relationships between income/prices and the consumption of calories and nutrients.

Calorie-income elasticities have been frequently estimated. In an African context, studies are available for Tanzania (Abdulai and Aubert 2004b), Kenya (Bouis, Haddad, and Kennedy 1992), Rwanda (von Braun, de Haen, and Blanken 1991), and Sierra Leone (Strauss 1984). However, calorie-income elasticities do not allow inference about the consumption of micronutrients (Skoufias et al. 2009). For instance, a calorie-income elasticity close to zero does not necessarily imply a low incomeresponsiveness for micronutrient consumption. When food-insecure households experience an income shock, they typically reduce more expensive, micronutrient-rich foods such as meat and vegetables first and maintain their calorie consumption from staple foods to avoid hunger and immediate loss in physical productivity. Calorie-food price elasticities are even less suitable for inference about the nutrient consumption effects, due to the complex substitutability in food demand. Therefore, going beyond calories and explicitly analyzing consumption effects for various nutrients is critical, particularly when people suffer from multiple nutritional deficiencies, as is often the case in developing countries (Ramakrishnan 2002).

Knowledge about the effects of income and price changes on micronutrient malnutrition is scarce, especially for Sub-Saharan Africa. The only study that provides income and (few) price elasticities for several micronutrients is by Abdulai and Aubert (2004a), who use household data from Tanzania. Income and selected price elasticities for key micronutrients such as iron and vitamin A can also be found in Behrman and Deolalikar (1987) for rural South India, Pitt (1983) for rural Bangladesh, Behrman and Wolfe (1984) for Nicaragua, and Skoufias et al. (2009) for Mexico. However, as Skoufias et al. (2009) note, elasticity estimates substantially differ between countries and nutrients, so that the transferability of empirical results is low. We extend this line of research by developing an approach that allows consistent estimation of income and price elasticities for a variety of nutrients. This approach is used for empirical analyses in Malawi.

In particular, we use representative household survey data from Malawi to analyze typical food and nutrient consumption patterns and assess the state of calorie and nutrient deficiencies. Moreover, we present a complex demand system model allowing for quadratic Engel curves and estimate income (expenditure) and price elasticities for 23 food groups. From these food demand elasticities, we derive elasticities for the consumption of the minerals iron and zinc as well as of vitamin A, the three B vitamins riboflavin, folate, and vitamin B12, and vitamin $\mathrm{C}$, in addition to calories and protein. ${ }^{1}$ Finally, we

\footnotetext{
${ }^{1}$ For the sake of legibility, we frequently refer to calories as a nutrient inaccurately from a nutritionist perspective. We carried out the analysis for a few additional vitamins, for which deficiencies are not widespread in Malawi, however. Those
} 
combine the derived elasticities with estimates of people's nutritional status to simulate the potential impacts of income- and price-related policies on nutrient consumption and the prevalence of nutritional deficiencies.

Malawi, where almost 90 percent of the population lives in rural areas, has one of the lowest per capita income levels in the world. More than half of the population live below the national poverty line, and more than one-fifth are considered ultra poor (World Bank 2007). The country's economy is heavily dependent on agriculture; three-quarters of the population draw their main livelihood from farming. Most of the farming households grow maize, the main staple food, but less than one-fifth of them produce surplus and sell their produce (World Bank 2007). Survey results confirm that food-related shocks are devastating for people's well-being, and seasonal food shortages are common (World Bank 2007). Over the past decade, Malawi has undergone two major food deficits, leading to a famine in 2002 and a serious food emergency in 2005; in recent years, it has also experienced record maize surpluses (Denning et al. 2009). The country has a long history of maize price regulations and has gone through several agricultural market reforms (Harrigan 2003, 2008).

Since many Malawians have faced chronic or seasonal food shortages in the past, we expect that calorie acquisition is a significant priority for households; therefore, cheapening the price of the main staple food (maize) may crowd out other nutritious foods, causing higher risks of mineral and vitamin deficiencies. In contrast, changes in household income do not affect relative food prices, so rising incomes - for instance, through cash transfers - are likely to contribute to higher consumption across all nutrients. These hypotheses are tested in the present article. If confirmed, this would imply that consumer price subsidies for selected staple foods, which are observed in several African countries with the intention to improve food and nutrition security, may need to be reconsidered.

The rest of this article is structured as follows. The second section presents the database and the nutritional assessment method, which is then used for calculating patterns of nutritional deficiencies in Section 3. The fourth section describes and discusses the demand systems approach for estimating income and price elasticities. The fifth section presents the estimation results, which are used for the policy simulations in Section 6. The last section concludes.

additional results are not shown for brevity. Unfortunately, iodine could not be included, because the underlying survey data provide no information on whether the salt consumed by households is iodized or not. Globally, including in Sub-Saharan Africa, the prevalence of iodine deficiency disorders has been reduced significantly through increased coverage with iodized salt (Sanghvi et al. 2007). The Micronutrient Initiative et al. (2009) estimate that half of all Malawian households consume iodized salt in adequate amounts. 


\section{DATA AND THE NUTRITIONAL ASSESSMENT APPROACH}

This study uses data from the second Malawi Integrated Household Survey (IHS), carried out from March 2004 through March 2005. The sample comprises 11,280 households and is representative nationwide at the district level and for rural and urban areas. The food consumption module of the IHS provides the main data for our analysis.

\section{Estimation of Food and Nutrient Consumption}

Household food consumption was surveyed using a seven-day recall. It reports consumed quantities for more than 100 food items (including beverages other than water) and differentiates them according to their sources such as from own production, market purchases, and food gifts. Expenditures for purchased foods are recorded as well. ${ }^{2}$ To calculate nutrient consumption amounts from the reported food quantities, we applied conversion factors of the World Food Dietary Assessment System (FAO 2010), primarily for Kenya and Senegal, which are the only available databases for Sub-Saharan Africa. For each household, we aggregated food consumption quantities and nutrient amounts into 23 food subgroups and five basic food groups (meaning staple foods, pulses, vegetables and fruits, animal products, and meal complements) and converted them on a per capita and per day basis. Our choice of food group aggregation takes account of the typical composition of Malawian meals and the nutritional characteristics of foods.

\section{Estimation of Nutrient Deficiencies}

To assess nutritional status, we compare per capita nutrient consumption amounts with appropriate reference levels for adequacy from the literature. Since food consumption in the IHS is reported at the household level, we assume that food is distributed equally within the household according to the relative nutrient requirements of household members. We use international standard recommendations and requirements for individuals as suggested by the Food and Agriculture Organization of the United Nations (FAO) and the World Health Organization (WHO), based on which we calculate household-specific reference values, taking household size, age, and sex composition into consideration. The prevalence of a particular deficiency is determined as the percentage of people with consumption levels below their calculated requirements.

To compute calorie recommendations and requirements we apply the recommended mean energy intakes available from FAO, WHO, and the United Nations University (UNU) (2001). We define calorie recommendations for all individuals as average requirements necessary to maintain a normal lifestyle with a moderate physical activity level (PAL) and a median body mass index (BMI) of 21.0 among adults. Minimum calorie requirements are defined as requirements needed for a light PAL and a low BMI of 18.5. The calculation of BMIs for adults is based on average height values from the literature (NSO/ORC Macro 2005; Pelletier, Low, and Msukwa 1991). For protein, recommendations and requirements are derived from the safe levels of protein intake given by FAO, WHO, and UNU (1985) and determined for average and low BMIs, respectively. For micronutrients, the two reference levels are recommended nutrient intakes (RNIs) and estimated average requirements (EARs). RNIs are available from WHO and FAO (2004); they also provide the basis for calculating EARs, applying conversion factors reported in WHO and FAO (2006). For iron and zinc, where issues of bioavailability are of

\footnotetext{
${ }^{2}$ The absence of consistent information on food market prices requires the use of unit values calculated from reported food quantities and expenditures. Missing unit values are predicted item-specifically following the concept of opportunity values. We assume that products of equal quality have the same value at the same place and at an equal point in time, independent of their source. To avoid inconsistencies in price elasticity estimates due to consumer quality choice, measurement errors in food quantities and expenditures (Deaton 1988), and economies of scale in purchase, we employ a price approximation procedure as presented by Alfonzo and Peterson (2006). That is, we adjust unit values for the systematic changes in unit costs and account for the composition of food aggregates. We explicitly allow for spatial and temporal variation in food prices.
} 
particular concern, we assume low bioavailability, because staple food crops are the major source of these minerals in typical Malawian diets.

\section{Limitations and Adjustments}

Using food consumption recalls from household surveys for nutritional assessment has certain drawbacks in terms of accuracy. First, respondents might not remember the exact quantities consumed, especially when the recall period is long. Second, food consumption recalls capture the total food entering the household, not all of which is actually consumed by household members. Some amounts might be fed to pets, wasted, or given to guests or hired laborers. This can lead to an overestimation of actual food intake, especially in richer households (Bouis 1994). Third, household consumption surveys do not capture intrahousehold food distribution and therefore necessitate assuming an equal distribution of food among household members. Ignoring intrahousehold inequality can lead to a misspecification of prevalence estimates in both directions (Haddad and Kanbur 1990). Fourth, food records are not usually itemized for individual meals, so adjustments for the bioavailability of micronutrients due to enhancing or inhibiting factors in certain foods cannot be made. Thus, assumptions on bioavailability have to be based on common dietary patterns. Although these general drawbacks have to be kept in mind, the resulting inaccuracies might be fairly small in our case. The seven-day recall period used in the IHS is relatively short, so that data recording should be fairly precise. Issues of seasonality in food consumption, which are usually a problem in single-round surveys, are of lesser concern here, because the data were collected over the period of an entire year. In addition, we dropped household observations showing biologically implausible calorie consumption values and adjusted sample weights accordingly. ${ }^{3}$

Some authors have also voiced more specific criticism related to nutritional assessment studies based on household survey data, especially in terms of determining the prevalence of nutritional deficiencies using general cut-off levels (for example, Gibson 2005; Svedberg 2000). Nutrient intake reference levels are defined for the average daily need over a reasonable, but usually unspecified, period of time that might not be properly reflected in a single-round food recall. They are defined for groups of individuals of the same sex, age, and physiological status and refer to intake levels required to maintain good health and development in healthy and well-nourished individuals (FAO/WHO/UNU 2001; WHO/FAO 2004). Especially the definition of calorie requirement levels for adults has been criticized for the assumptions of identical body composition of individuals (of the same population group), uniform physical activity levels of individuals across the population, and identical calorie use for internal body functions in individuals (Svedberg 2000). Moreover, assuming good health might be of concern in a developing-country context and particularly in populations affected by widespread parasitic infections. Unfortunately, most existing survey data, including the IHS, do not allow for consistent adjustments of individual health status, body composition, physical activity, and physiological nutrient requirements, and more accurate reference levels are not available from the literature. Following the common convention, our principal assumption is hence that the calculated nutrient requirements reflect the likely minimum nutritional needs but not necessarily the actual ones.

We are aware of these limitations and therefore stress that the exact results should be interpreted with some caution. Nevertheless, since individual-level food intake and clinical assessment data are hardly ever available for developing countries on a representative, population-wide basis, our analysis can provide important and, in certain ranges, reasonable information on the overall nutrition situation. It should be mentioned that the use of representative household survey data is already a notable improvement over much cruder methods that are often used for assessing the prevalence of undernutrition in developing countries (Smith, Alderman, and Aduayom 2006).

\footnotetext{
${ }^{3}$ We considered a household as an outlier if its per capita calorie consumption was below 500 kilocalories (kcal) or above $5,000 \mathrm{kcal}$ per day. The final dataset comprises 10,370 households (9,090 from rural areas and 1,280 from urban areas).
} 


\section{FOOD AND NUTRIENT CONSUMPTION AND DEFICIENCIES}

Food consumption in Malawi is generally characterized by a high risk of malnutrition. Table 1 shows that average consumption amounts for many essential nutrients fall short of or just exceed the average recommended nutrient intakes for a healthy diet. Mean calorie consumption exceeds the recommendation by 6 percent. Mean nutrient consumption amounts are inadequate to meet the recommended levels for iron, zinc, vitamin A, and vitamin B12; the consumption of vitamin B12 even falls short of the requirement level. However, mean values mask considerable variation across households. Standard deviations indicate that there is a relatively high degree of inequality in the consumption of many nutrients across the population. This, together with high correlation between the nutrient amounts consumed, implies that many Malawians are vulnerable to multiple nutritional deficiencies.

Table 1. Food and nutrient consumption and prevalence of nutritional deficiencies

\begin{tabular}{|c|c|c|c|c|c|}
\hline & $\begin{array}{c}\text { Quantity } \\
\text { (g) }\end{array}$ & $\begin{array}{c}\text { Calories } \\
(\text { kcal })\end{array}$ & $\begin{array}{c}\text { Protein } \\
\text { (g) }\end{array}$ & $\begin{array}{l}\text { Iron } \\
(m g)\end{array}$ & $\begin{array}{l}\text { Zinc } \\
(m g)\end{array}$ \\
\hline Staple foods & 512.0 & 1594 & 35.30 & 14.09 & 7.48 \\
\hline Maize & 381.7 & 1332 & 30.47 & 12.71 & 6.65 \\
\hline Rice & 14.2 & 52 & 0.95 & 0.09 & 0.16 \\
\hline Other cereals & 23.3 & 76 & 2.22 & 0.44 & 0.28 \\
\hline Cassava & 51.4 & 91 & 0.77 & 0.55 & 0.21 \\
\hline Potatoes $^{\mathrm{a}}$ & 41.4 & 44 & 0.89 & 0.30 & 0.19 \\
\hline Pulses & 65.1 & 235 & 14.19 & 3.65 & 1.84 \\
\hline Regular beans & 23.7 & 78 & 5.35 & 1.79 & 0.67 \\
\hline Peas \& soybeans & 18.0 & 61 & 4.37 & 0.98 & 0.58 \\
\hline Groundnuts & 23.3 & 96 & 4.47 & 0.88 & 0.60 \\
\hline Vegetables \& fruits & 161.3 & 63 & 1.59 & 0.81 & 0.26 \\
\hline Tomato & 19.3 & 4 & 0.17 & 0.10 & 0.02 \\
\hline Pumpkin & 35.5 & 7 & 0.18 & 0.07 & 0.07 \\
\hline Green leafy vegetables & 45.8 & 9 & 0.58 & 0.34 & 0.05 \\
\hline Other vegetables & 12.8 & 4 & 0.20 & 0.13 & 0.04 \\
\hline Bananas & 13.1 & 14 & 0.12 & 0.06 & 0.02 \\
\hline Fruits & 34.8 & 25 & 0.33 & 0.11 & 0.05 \\
\hline Animal products & 50.8 & 74 & 10.75 & 0.34 & 0.58 \\
\hline Eggs & 3.1 & 5 & 0.39 & 0.04 & 0.03 \\
\hline Fish & 29.0 & 39 & 7.77 & 0.16 & 0.23 \\
\hline Red meat & 6.5 & 14 & 1.18 & 0.07 & 0.18 \\
\hline White meat & 5.4 & 11 & 1.04 & 0.06 & 0.09 \\
\hline Milk \& dairy products & 6.9 & 5 & 0.38 & 0.01 & 0.05 \\
\hline Meal complements & 96.2 & 206 & 0.14 & 0.07 & 0.00 \\
\hline Fat $\&$ oil & 11.7 & 103 & 0.00 & 0.00 & 0.00 \\
\hline Sugar \& sweets & 23.3 & 73 & 0.00 & 0.02 & 0.00 \\
\hline Condiments & 10.4 & 4 & 0.01 & 0.04 & 0.00 \\
\hline Beverages & 50.7 & 26 & 0.13 & 0.01 & 0.00 \\
\hline TOTAL & 885.4 & 2171 & 61.97 & 18.96 & 10.17 \\
\hline Standard deviations & 421.5 & 928 & 31.26 & 8.71 & 4.61 \\
\hline Recommendations & & 2044 & 33.36 & 30.20 & 11.86 \\
\hline Requirements & & 1702 & 31.72 & 17.22 & 9.90 \\
\hline Prevalence of deficiency (\%) & & 34.8 & 12.4 & 47.1 & 54.5 \\
\hline & $\begin{array}{l}\text { Vit. } A^{b} \\
(\mu g R E)\end{array}$ & $\begin{array}{c}\text { Riboflavin } \\
\text { (mg) }\end{array}$ & $\begin{array}{c}\text { Folate }^{c} \\
(\mu g D F E)\end{array}$ & $\begin{array}{c}\text { Vit. B12 } \\
(\mu g)\end{array}$ & $\begin{array}{c}\text { Vit. C } \\
\text { (mg) } \\
\end{array}$ \\
\hline Staple foods & 40.5 & 0.793 & 134.0 & 0.002 & 28.87 \\
\hline Maize & 0.5 & 0.739 & 110.7 & 0.000 & 3.17 \\
\hline Rice & 0.0 & 0.009 & 0.9 & 0.000 & 0.00 \\
\hline Other cereals & 0.7 & 0.020 & 5.7 & 0.002 & 0.01 \\
\hline Cassava & 4.1 & 0.014 & 10.4 & 0.000 & 20.68 \\
\hline Potatoes $^{\mathrm{a}}$ & 35.3 & 0.012 & 6.3 & 0.000 & 5.02 \\
\hline
\end{tabular}


Table 1. Continued

\begin{tabular}{|c|c|c|c|c|c|}
\hline & 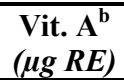 & $\begin{array}{c}\text { Riboflavin } \\
\text { (mg) }\end{array}$ & $\begin{array}{c}\text { Folate }^{\mathrm{c}} \\
(\mu g D F E)\end{array}$ & $\begin{array}{c}\text { Vit. B12 } \\
(\mu g)\end{array}$ & $\begin{array}{c}\text { Vit. C } \\
\text { (mg) }\end{array}$ \\
\hline Pulses & 2.4 & 0.106 & 176.1 & 0.000 & 2.25 \\
\hline Phaseolus beans & 0.0 & 0.036 & 79.8 & 0.000 & 0.71 \\
\hline Peas \& soybean & 2.2 & 0.049 & 66.5 & 0.000 & 1.47 \\
\hline Groundnuts & 0.2 & 0.021 & 29.8 & 0.000 & 0.07 \\
\hline Vegetables \& fruits & 337.6 & 0.083 & 64.8 & 0.000 & 44.80 \\
\hline Tomato & 16.8 & 0.010 & 2.9 & 0.000 & 3.66 \\
\hline Pumpkin & 71.4 & 0.004 & 5.0 & 0.000 & 1.78 \\
\hline Green leafy vegetables & 199.2 & 0.031 & 40.5 & 0.000 & 12.08 \\
\hline Other vegetables & 6.5 & 0.010 & 3.4 & 0.000 & 1.08 \\
\hline Bananas & 6.9 & 0.010 & 3.0 & 0.000 & 1.32 \\
\hline Fruits & 36.7 & 0.019 & 10.0 & 0.000 & 24.88 \\
\hline Animal products & 11.8 & 0.071 & 6.6 & 0.897 & 0.36 \\
\hline Eggs & 5.8 & 0.016 & 1.3 & 0.034 & 0.00 \\
\hline Fish & 2.7 & 0.021 & 4.1 & 0.721 & 0.22 \\
\hline Red meat & 0.0 & 0.009 & 0.3 & 0.078 & 0.00 \\
\hline White meat & 1.1 & 0.009 & 0.2 & 0.021 & 0.01 \\
\hline Milk \& dairy products & 2.3 & 0.017 & 0.6 & 0.043 & 0.13 \\
\hline Meal complements & 0.4 & 0.016 & 2.8 & 0.007 & 0.71 \\
\hline Fat $\&$ oil & 0.0 & 0.000 & 0.0 & 0.000 & 0.00 \\
\hline Sugar \& sweets & 0.0 & 0.004 & 0.0 & 0.000 & 0.00 \\
\hline Spices & 0.2 & 0.000 & 0.2 & 0.000 & 0.16 \\
\hline Beverages & 0.2 & 0.012 & 2.5 & 0.007 & 0.56 \\
\hline TOTAL & 392.8 & 1.068 & 384.3 & 0.906 & 76.99 \\
\hline Standard deviations & 473.0 & 0.476 & 261.5 & 1.811 & 98.34 \\
\hline Recommendations & 525.3 & 0.994 & 332.4 & 1.867 & 39.25 \\
\hline Requirements & 375.4 & 0.829 & 265.9 & 1.549 & 32.21 \\
\hline Prevalence of deficiency (\%) & 65.6 & 32.8 & 37.3 & 84.1 & 33.8 \\
\hline
\end{tabular}

Source: Compiled by authors.

Notes: Food quantities and nutrient consumption amounts are reported per capita and day. The average person equals 0.785 adult (male) equivalences, based on calorie requirement reference levels. All estimates are based on edible portion sizes.

${ }^{a}$ Potatoes also include sweetpotatoes, some varieties of which are orange fleshed containing provitamin A.

${ }^{\mathrm{b}} \mathrm{RE}=$ retinol equivalences.

${ }^{\mathrm{c}} \mathrm{DFE}=$ dietary folate equivalences.

Comparison with available estimates from previous studies suggests that our results are reasonable. Our analysis reveals that 35 percent of the Malawian population suffers from calorie deficiency, which exceeds the FAO estimates on the proportion of undernourished of 29 percent for 2004-2006 (FAO/WFP 2009). The FAO result is based on national food balance sheet data; Smith, Alderman, and Aduayom (2006) showed that such data can easily result in underestimation of the prevalence of nutritional deficiencies, and therefore our estimate is likely to be more precise. The 2004 Demographic Health Survey reveals a poor nutritional status of many Malawian children: 48 percent of the children under five are stunted, 5 percent are wasted, and 22 percent are underweight (NSO/ORC Macro 2005). Our estimate of the iron deficiency prevalence rate of 47 percent is in line with the 2001 National Micronutrient Survey (NSO/ORC Macro 2005), according to which 80 percent of children under five, 27 percent of nonpregnant women, and 17 percent of men are anemic. For zinc deficiency, our estimate of 55 percent is higher than the 34 percent reported by the International Zinc Nutrition Consultative Group (IZiNCG) (2004). However, the IZiNCG estimates are again derived from FAO food balance sheets and are thus less reliable than our estimates. Only for vitamin A, our prevalence estimate of 66 percent might be somewhat overstated. The 2001 National Micronutrient Survey shows that 60 percent of children under five, 57 percent of nonpregnant women, and 38 percent of men suffer from vitamin A deficiency (NSO/ORC Macro 2005). 
Table 1 reveals that food consumption in most Malawian households is poorly diversified - a fact that substantially contributes to micronutrient malnutrition. On average, more than 60 percent of the total food quantity consists of staple foods, primarily maize. Maize accounts for 46 percent of total food quantity, more than 60 percent of energy, and almost half of protein consumption. ${ }^{4}$ It is also the source for 67 percent of total iron, 65 percent of total zinc, and almost 70 percent of total riboflavin consumed. Particularly when animal-source foods are scarce in the diet, low consumption of vegetables and fruits is often the main cause of micronutrient deficiencies (Ruel, Minot, and Smith 2005). On average, vegetable and fruit consumption is below 200 grams per day, which is less than half the minimum recommended intake for a healthy diet (WHO/FAO 2003). Nonetheless, vegetables and fruits account for 86 percent of vitamin A consumption, of which almost 60 percent is provided by green leafy vegetables. The low vitamin B12 level results from a generally low consumption of meat and fish. Given the country's location bordering Lake Malawi, fish is the lowest-priced and most consumed animal-source food. It accounts for 80 percent and 13 percent of vitamin B12 and protein consumption, respectively.

These patterns clearly reflect a dietary choice that is focused on avoiding calorie shortages driven by poverty. The IHS shows that 56 percent of the rural population is poor and 25 percent ultra poor, compared with 25 percent and 8 percent of the urban population, respectively (World Bank 2007). ${ }^{5}$ Thus, food demand patterns are likely to differ between rural and urban households. In urban areas, mean per capita food expenditure (including opportunity values for own-produced foods) equals 52.39 Malawi kwacha (MK), which is almost double the amount spent in rural areas (27.14 MK). Accordingly, the average food budget share is significantly lower among urban (60 percent) than among rural households (76 percent). Rural households spend 47 percent of their food budget on staples and 35 percent on maize alone, whereas for urban households the shares are 37 percent and 21 percent, respectively (see tables A1 and $\mathrm{A} 2$ in the appendix for details).

To get a first impression of how food consumption is associated with income and prices, we carry out a simple correlation analysis, results of which are shown in Table 2. The coefficients indicate positive correlation between income (expenditure) and calorie consumption among both rural and urban households. However, higher incomes are associated with lower maize consumption in urban households, whereas the opposite holds true in the poorer rural households. This difference calls for separate estimation of food demand elasticities in rural and urban areas and use of a complete demand systems approach to properly capture substitution effects. Correlation coefficients with respect to the Food Variety Score (FVS) - a common measure of dietary diversity - show that higher income comes along with a more diversified diet in both rural and urban areas. ${ }^{6}$ Likewise, a lower maize price is associated with the consumption of a larger number of different, not necessarily more nutritious, foods. However, these results should not be overinterpreted in terms of nutritional impacts of income and price policies. This requires more sophisticated analysis, as discussed in the following.

Table 2. Correlations of key nutrition and economic indicators among rural and urban households

\begin{tabular}{|c|c|c|c|c|c|c|}
\hline \multirow[b]{3}{*}{ Calorie consumption } & \multicolumn{2}{|c|}{ Rural } & \multicolumn{4}{|c|}{ Urban } \\
\hline & Total expenditure & Maize price & \multicolumn{2}{|c|}{ Total expenditure } & \multicolumn{2}{|c|}{ Maize price } \\
\hline & $0.280 \quad * * *$ & $-0.076 * * *$ & 0.249 & $* * *$ & 0.017 & \\
\hline Maize consumption & 0.082 & -0.060 & -0.133 & $* * *$ & 0.033 & \\
\hline Food Variety Score & 0.288 & -0.159 & 0.312 & $* * *$ & -0.058 & $* *$ \\
\hline
\end{tabular}

Source: Compiled by authors.

Notes: Calorie and maize consumption and total expenditure (in Malawi kwacha $[\mathrm{MK}]$ ) are calculated per capita and day, and the price of maize (in MK) per kilogram.

$*, * *, * * *$ : coefficient is statistically significant at the $10 \%, 5 \%$, and $1 \%$ level, respectively.

\footnotetext{
${ }_{5}^{4}$ All figures on total food quantity given in the text exclude beverages.

${ }^{5}$ The National Statistical Office of Malawi classifies only the four major cities Lilongwe, Blantyre, Zomba, and Mzuzu as urban areas (NSO 2005).

${ }^{6}$ The FVS is a simple count of the number of different foods eaten in a household over the surveyed week; we exclude condiments and beverages from the count.
} 


\section{METHODOLOGY FOR ELASTICITY ESTIMATION}

\section{Analytical Framework}

For estimating nutrient consumption elasticities with respect to household income and food prices, two basic approaches are available that are both rooted in neoclassical consumer theory. In the first approach, the "demand" for a particular nutrient is expressed as a direct function of income and prices and estimated by a single equation. Nutrient elasticities are directly derived from the estimated parameters. This approach theoretically emerges from Lancaster's good characteristics model, according to which the characteristics of a good (or a bundle of goods) such as nutrient content, taste, texture, color, prestige, and so forth give utility to consumers and not the good per se (Lancaster 1971). Such nutrient consumption models are often referred to as reduced-form demand models. They are simple to estimate and have been used in previous empirical analyses (for example, Abdulai and Aubert 2004a; Bouis 1994). A weakness of these models is their underlying, strong assumption on consumers' information and their implication for the principle axiom of utility maximization in demand theory. Whereas assuming intentional food choice according to calorie needs might be reasonable for populations affected by food insecurity, the assumption might be less defendable with respect to micronutrients, given a generally poor nutritional knowledge and the absence of an immediate physiological response in situations of undersupply. Another drawback is that any single-equation model falls short of incorporating mutual interdependencies between goods in consumer demand, which occur under budget constraints and reflect in relative prices (Sadoulet and de Janvry 1995).

The second approach proceeds in two steps. In the first step, the demand for foods is modeled. In the second step, the derived food demand elasticities are translated into elasticities of nutrient consumption, based on technical coefficients that measure nutrient contents in foods. Thus, food demand is considered as the actual reflection of consumer preferences, whereas the "demand" for nutrients is latent. This approach allows estimation of a fully specified demand system with the relevant restrictions emerging from economic theory. Moreover, it is better able to capture interdependencies and substitution effects between foods when prices change, so that it is clearly the preferred option in our particular context. Although a few studies have estimated highly aggregated demand systems to derive calorie elasticities (for example, Pitt 1983; Strauss 1984), hardly any previous work has used a complete systems framework to estimate micronutrient elasticities. One exception is Huang (1996), who used a differentialform demand system and data from the United States. We extend this body of literature in a development context by estimating a more complex demand model that incorporates the quadratic almost ideal demand system (QUAIDS) for modeling food and nutrient demand.

Economists who seek to investigate patterns of demand are always facing the problem that consumption choices involve decisions on a large number of goods. If each good consumed were assigned to a separate category in a demand system, the model would become too complex for estimation. This calls for aggregation of commodities into groups. However, for obtaining reliable food and nutrient elasticities, a low degree of aggregation needs to be maintained. The level of aggregation at which the fixed food-nutrient conversion factors are applied is critical, since intragroup food substitution and increases in the price per nutrient, resulting from nonnutritive quality choice as income rises, are ignored (Behrman and Deolalikar 1987). Hence, aggregation leads to an upward bias in nutrient elasticities. A practical avenue out of this dilemma is to assume a priori some structure in consumer preferences (Edgerton 1997).

\section{Multistage Budgeting}

The usual assumption is that of a multistage decision process, where expenditure is allocated between commodity groups based on price indexes, and where expenditure allocation within groups is performed independently. The necessary conditions for multistage budgeting to be consistent with a complete demand system are weak separability of consumer preferences and low variability of group price indexes 
with expenditure (Edgerton 1997). Assuming these conditions allows one to model conditional demand at each budgeting stage independently, and to add up estimated conditional elasticities to total (or unconditional) elasticities over stages. This procedure constrains cross-group price effects to be channeled through group expenditures, while price changes in a commodity group affect consumption quantities within the same commodity directly (Edgerton 1997). Multistage budgeting has been applied in combinations with almost ideal demand systems (AIDSs) in two-stage systems (for example, Gao, Wailes, and Cramer 1996; Heien and Wessells 1990) and three-stage systems (, Edgerton 1997; Jiang and Davis 2007).

We assume a three-stage budgeting process, where households first decide on the allocation of the total budget to food and nonfood commodities. Since price information is not available for most nonfood items, a Working-Leser model is applied at the first stage. At the second stage, the food budget is allocated to five basic food groups. Each group is then further disaggregated into three to six subgroups, leading to a total of 23 food subgroups at the third stage. The QUAIDS is used at the second and third stage. In total, 12 QUAIDSs are estimated: six each for rural and urban households. Out of the six, the first estimates parameters for the five basic food groups in the second budgeting stage, whereas the other five refer to the further disaggregated models in the third budgeting stage.

\section{Working-Leser Model}

For modeling household decisions on allocating total expenditure, we follow Working's (1943) specification and control for price changes between food and nonfood commodities by including an aggregated food price index. The expenditure share for food $\left(w_{F}\right)$ is thus given by

$$
w_{F}=\alpha_{F}+\gamma_{F} \ln p_{F}+\beta_{F} \ln M,
$$

where $p_{F}$ denotes the average food price and $M$ the total per capita household expenditure. To control for effects of sociodemographic factors in budget allocation, we use a linear demographic translation through the intercept (Pollak and Wales 1981). We account for household size, sex and age composition, education of the decisionmaker, and access to the nearest daily market. The computation of conditional expenditure and Marshallian price elasticities from equation (1) follows Leser's (1963) formulation.

\section{Quadratic Almost Ideal Demand System}

The linear approximate form of the almost ideal demand system (LA/AIDS), which was popular for empirical studies in the 1980s and 1990s, has been criticized more recently for yielding biased and inconsistent estimates in many cases ( Asche and Wessells 1997). Banks, Blundell, and Lewbel (1997) demonstrated that the appropriate form for some consumer preferences is of quadratic nature, suggesting the generalization of the basic AIDS. To account for this, they introduced the quadratic version (QUAIDS), which nests the AIDS and allows for the flexibility of a rank-three specification in the Engel curves. According to Banks, Blundell, and Lewbel, the QUAIDS has indirect utility functions $(V)$ of the form

$$
\ln V=\left\{\left[\frac{\ln m-\ln a(p)}{b(p)}\right]^{-1}+\lambda(p)\right\}^{-1},
$$

where $m$ indicates total food or food group expenditure and $p$ is a vector of food prices. The term in squared brackets is the indirect utility function of a demand system of the price-independent generalized logarithmic (PIGLOG) preference class. The functions $\ln a(p)$ and $b(p)$ are the translog and the CobbDouglas price aggregator functions defined by

$$
\ln a(p)=\alpha_{0}+\sum_{i=1}^{n} \alpha_{i} \ln p_{i}+\frac{1}{2} \sum_{i=1}^{n} \sum_{j=1}^{n} \gamma_{i j} \ln p_{i} \ln p_{j}
$$


and

$$
b(p)=\prod_{i=1}^{n} p_{i}^{\beta_{i}}
$$

The price aggregator function $\lambda(p)$ is given by

$$
\lambda(p)=\sum_{i=1}^{n} \lambda_{i} \ln p_{i}
$$

as

Applying Roy's identity to equation (2), food budget shares for each food group can be expressed

$$
w_{i}=\alpha_{i}+\sum_{j=1}^{n} \gamma_{i j} \ln p_{j}+\beta_{i} \ln \left[\frac{m}{a(p)}\right]+\frac{\lambda_{i}}{b(p)}\left\{\ln \left[\frac{m}{a(p)}\right]\right\}^{2} .
$$

The theoretical restrictions of adding up, homogeneity, and Slutsky symmetry are imposed in the basic QUAIDS by setting

$$
\begin{gathered}
\sum_{i=1}^{n} \alpha_{i}=1 \sum_{i=1}^{n} \beta_{i}=0 \sum_{i=1}^{n} \lambda_{i}=0 \sum_{j=1}^{n} \gamma_{i j}=0, \\
\sum_{i=1}^{n} \gamma_{i j}=0
\end{gathered}
$$

and

$$
\gamma_{i j}=\gamma_{j i}
$$

From equation (6), it can be seen that the QUAIDS collapses to the AIDS when all $\lambda_{i}$ equal zero. ${ }^{7}$ In conformity with the first budgeting stage, we allow for linear sociodemographic translation through the intercept in equation set (6).

\section{Censoring}

Using household budget survey data for demand system estimation often creates a major problem that is due to recording zero expenditure for food groups that are not consumed during the recall period. This causes censored dependent variables and leads to biased results when not accounted for. Heien and Wessells (1990) introduced a computationally simple, two-step estimation procedure based on Heckman's (1979) work. However, Shonkwiler and Yen (1999) demonstrated the inconsistency of Heien and Wessells's procedure and proposed an alternative and consistent two-step estimation procedure. We adopt this approach here to satisfy the consistency property of demand systems.

In both steps of the two-step procedure, all observations of the sample are applied. The first step obtains household-specific probit estimates $\hat{\omega}_{h}$ of $\omega_{h}$ that take the binary outcome of one if household $h$ consumes food items of the considered food aggregate, and zero otherwise. The univariate standard normal probability density $\phi\left(x_{h l_{x}} \hat{\omega}_{h}\right)$ and the cumulative distribution $\Phi\left(x_{h l_{x}} \hat{\omega}_{h}\right)$ are calculated for each

\footnotetext{
${ }^{7}$ The index $i$ refers to the considered food group, and $j$ to any food group in the system; $n$ denotes the total number of food groups in the system.
} 
household by regressing $\omega_{h}$ on a set of independent variables $x_{h l_{x}}{ }^{8}$ In the second step, the probability density and the cumulative distribution are incorporated in the budget share equations, and the system is finally estimated. Thus, equation set (6) is replaced by

$$
w_{i}^{*}=\Phi\left(x_{h l_{x}}^{\prime} \hat{\omega}_{h}\right) w_{i}+\varphi_{i} \phi\left(x_{h l_{x}}^{\prime} \hat{\omega}_{h}\right) .
$$

Unlike in the conventional system specification without censoring, the deterministic components on the right-hand side of equation set (10) do not add up to unity across all equations of the system in general, and so the error terms in the estimation form do not add up to zero (Yen, Kan, and Su 2002).

Thus, the usual procedure of imposing the adding-up restriction $\left(\sum_{i=1}^{n} \alpha_{i}=1\right)$ on the system and dropping one arbitrary equation is not valid. Therefore, with censoring, the second step of the system (equation set 10 ) is estimated correctly when using the entire set of $n$ equations (Yen, Kan, and $\mathrm{Su} 2002$ ).

\section{Food Demand Elasticities}

To derive conditional expenditure and price elasticities from the system, equation set (10) is differentiated with respect to $\ln m$ and $\ln p_{j}$, such that

$$
\mu_{i} \equiv \frac{\partial w_{i}^{*}}{\partial \ln m}=\Phi\left(x_{h l_{x}}^{\prime} \hat{\omega}_{h}\right)\left(\beta_{i}+\frac{2 \lambda_{i}}{b(p)}\left\{\ln \left[\frac{m}{a(p)}\right]\right\}\right)_{\mathrm{d}}
$$

and

$$
\mu_{i j} \equiv \frac{\partial w_{i}^{*}}{\partial \ln p_{j}}=\Phi\left(x_{h_{x}}^{\prime} \hat{\omega}_{h}\right)\left(\gamma_{i j}-\mu_{i}\left(\alpha_{j}+\sum_{k} \gamma_{j k} \ln P_{k}\right)-\frac{\lambda_{i} \beta_{j}}{b(p)}\left\{\ln \left[\frac{m}{a(p)}\right]\right\}^{2}\right)
$$

where $P_{k}$ is a price index calculated as the arithmetic mean of prices for all $k$ food groups. The conditional expenditure elasticities are then obtained by $E_{i}=\mu_{i} / w_{i}^{*}+1$. They are greater than unity at low expenditure levels and eventually become less than unity when total expenditure increases, while the term $\lambda_{i}$ becomes more important.

The conditional, Marshallian (or uncompensated) price elasticities are derived as $e_{i j}^{u}=\mu_{i j} / w_{i}^{*}-\delta_{i j}$, where $\delta_{i j}$ is the Kronecker delta equaling one when $i=j$, and zero otherwise. Using the Slutsky equation, the conditional, Hicksian (or compensated) price elasticities are given as $e_{i j}^{c}=\mu_{i j} / w_{i}^{*}+E_{i} w_{j}^{*}$. Hicksian price elasticities measure the relationship between the price of a particular commodity and the consumed quantity for a constant level of utility, and not for a constant level of income as the Marshallian price elasticities do. Thus, changes in consumer real incomes associated with price changes are captured by the Marshallian price elasticities. Given that food consumption in Malawi is highly constrained by household income, we are mainly interested in Marshallian price elasticities, whereas conditional Hicksian price elasticities are needed to compute unconditional Marshallian price elasticities.

\footnotetext{
${ }^{8}$ The vector $x_{h l_{x}}$ gives the determinants for consumption and nonconsumption of the food group under consideration. It includes own- and cross-prices, linear household food expenditure, a vector of household characteristics, and a vector identifying access to foods. All continuous variables enter in logarithmic form.
} 
In deriving unconditional expenditure and price elasticities, we follow Edgerton (1997). Computing the unconditional expenditure elasticities is straightforward by multiplying the conditional expenditure elasticities of each budgeting stage. The unconditional Marshallian price elasticities are derived as

$$
e_{i j}^{u}=\delta_{r s} e_{(r) i j}^{c}+E_{(r) i} w_{(s) j}^{*}\left(e_{r s}^{c}+E_{r} w_{s}^{*} e_{F}^{u}\right),
$$

where the indexes $i$ and $j$ represent the food subgroups at the third budgeting stage, $r$ and $s$ the basic food groups at the second budgeting stage, and $F$ food as aggregate at the first budgeting stage. The Kronecker delta of the second stage is indicated by $\delta_{r s}$.

Unconditional expenditure elasticities are positive for normal goods. Estimates above one imply an overproportional consumption increase with rising total expenditure, which is typical for luxury goods. Necessary goods such as basic foods usually have expenditure elasticities between zero and one, indicating that the quantity consumed increases with rising expenditure in absolute terms but decreases in relative terms. Expenditure elasticities are negative for inferior goods, whose consumption drops with rising expenditure. Unconditional (Marshallian) own-price elasticities measure the percentage change in the quantity consumed to the percentage change in the price of the same good. They usually take negative values, indicating that consumption decreases when the price increases. The demand for a good is (own)price elastic if the absolute elasticity value is greater than one, and inelastic if the absolute value is between zero and one. Cross-price elasticities, measuring the percentage change in the quantity consumed of a good to a percentage change in the price of another good, indicate substitutability between the goods when the value is positive and complementarity when the value is negative.

\section{Nutrient Elasticities}

In previous studies (for example, Pitt 1983; Sahn 1988), calorie elasticities with respect to expenditure and prices were directly derived from expenditure and price elasticities of food demand. We extend this approach for various nutrients and account for the usual composition of food aggregates. The nutrient elasticities with respect to expenditure $\left(E_{N}\right)$ and food prices $\left(e_{i N}\right)$ are calculated as follows:

$$
E_{N}=\frac{\sum_{j} \sum_{f} c_{j f N} s_{j f} q_{j} E_{j}}{\sum_{j} \sum_{f} c_{j f N} s_{j f} q_{j}}
$$

and

$$
e_{i N}=\frac{\sum_{j} \sum_{f} c_{j f N} s_{j f} q_{j} e_{i j}}{\sum_{j} \sum_{f} c_{j f N} s_{j f} q_{j}},
$$

where $c_{j f N}$ is a technical coefficient measuring the content of a particular nutrient $(N)$ in food item $f$ that belongs to food subgroup $j . s_{j f}$ denotes the average share of food item $f$ in $\operatorname{subgroup} j$, and $q_{j}$ specifies the average consumed quantity of food subgroup $j$.

Since expenditure and partly also price elasticities of food demand and nutrient consumption vary along the income distribution, due to intragroup food substitution and consumer quality preferences (Behrman and Deolalikar 1987), we compute all elasticities for rural and urban households both at means of expenditure quintiles for use in further calculations and at overall population means for ease of presentation and interpretation. 


\section{INCOME AND PRICE EFFECTS ON FOOD DEMAND AND NUTRIENT CONSUMPTION}

\section{Discussion of Expenditure Elasticities}

Table 3 shows selected expenditure elasticities of food demand. ${ }^{9}$ For food as a whole, the mean expenditure elasticity is about 0.89 in rural areas and 0.75 in urban areas. This is quite high in an international context but reflects the situation of widespread food insecurity in Malawi: almost 90 percent of the marginal income in rural areas and 75 percent in urban areas is spent on food, on average. The mean expenditure elasticity for staple food demand is identical for rural and urban households. Yet there are notable differences within the group of staples. For instance, cereals are more preferred than cassava, and the consumption of maize is more income-responsive in rural than in urban areas. As can be seen, rural consumers perceive cassava as inferior food. Large differences between rural and urban households can also be observed for nonstaple foods. With the exception of animal products, expenditure elasticities for the main food groups are higher in rural than in urban areas, which is consistent with lower rural household incomes. Likewise, they are generally higher for poorer than for richer households, with differences being more pronounced in urban than in rural areas. This is not surprising given that income distribution is more unequal in urban areas. ${ }^{10}$

Table 3. Expenditure and Marshallian own-price elasticities of food demand among rural and urban households at population means and for the poorest and richest quintiles

\begin{tabular}{|c|c|c|c|c|c|c|c|c|}
\hline & \multicolumn{6}{|c|}{ Expenditure elasticities } & \multicolumn{2}{|c|}{ Own-price elasticities } \\
\hline & \multicolumn{3}{|c|}{ Rural } & \multicolumn{3}{|c|}{ Urban } & \multirow{2}{*}{$\begin{array}{l}\text { Rural } \\
\text { Mean }\end{array}$} & \multirow{2}{*}{$\begin{array}{l}\text { Urban } \\
\text { Mean }\end{array}$} \\
\hline & Mean & Poorest & Richest & Mean & Poorest & Richest & & \\
\hline FOOD & 0.885 & 0.897 & 0.860 & 0.747 & 0.809 & 0.615 & & \\
\hline Staple foods & 0.801 & 0.831 & 0.751 & 0.801 & 0.992 & 0.542 & & \\
\hline Maize & 0.948 & 0.985 & 0.857 & 0.628 & 0.894 & 0.282 & -0.877 & -0.722 \\
\hline Rice & 0.892 & 0.865 & 0.860 & 0.904 & 1.149 & 0.581 & -0.816 & -0.959 \\
\hline Other cereals & 1.326 & 1.158 & 1.169 & 1.382 & 1.978 & 0.734 & -0.854 & -0.970 \\
\hline Cassava & -0.665 & -0.580 & -0.457 & 0.076 & 0.239 & 0.125 & 0.618 & -1.152 \\
\hline Potatoes & 0.712 & 0.801 & 0.598 & 1.004 & 1.165 & 0.715 & -0.770 & -1.248 \\
\hline Pulses & 0.892 & 0.901 & 0.870 & 0.146 & 0.327 & -0.093 & & \\
\hline Regular beans & 1.365 & 1.270 & 1.386 & 0.197 & 0.424 & -0.132 & -0.952 & 0.415 \\
\hline Peas \& soybeans & 0.704 & 0.720 & 0.717 & 0.158 & 0.360 & -0.100 & -0.867 & -0.758 \\
\hline Groundnuts & 0.744 & 0.765 & 0.729 & 0.413 & 0.856 & -0.266 & -0.821 & -0.013 \\
\hline Vegetables \& fruits & 0.939 & 0.970 & 0.894 & 0.310 & 0.364 & 0.240 & & \\
\hline Tomato & 1.373 & 1.420 & 1.302 & 0.291 & 0.362 & 0.209 & -1.094 & -1.181 \\
\hline Pumpkin & 1.080 & 1.054 & 1.102 & 0.368 & 0.386 & 0.372 & -0.810 & -0.767 \\
\hline Green leafy vegetables & 0.791 & 0.844 & 0.733 & 0.191 & 0.214 & 0.194 & -0.932 & -0.816 \\
\hline Other vegetables & 0.818 & 0.921 & 0.725 & 0.335 & 0.445 & 0.205 & -0.847 & -0.873 \\
\hline Bananas & 0.563 & 0.722 & 0.438 & 0.278 & 0.324 & 0.221 & -1.035 & -0.896 \\
\hline Fruits & 0.603 & 0.721 & 0.510 & 0.331 & 0.379 & 0.260 & -0.923 & -0.461 \\
\hline
\end{tabular}

\footnotetext{
${ }^{9}$ Detailed results of the parameter estimates at the various budgeting stages, which were used to calculate the elasticities, are shown in appendix tables A3 to A5.

${ }^{10}$ The Gini coefficient of the expenditure distribution is 0.34 and 0.48 in rural and urban areas, respectively (World Bank 2007).
} 
Table 3. Continued

\begin{tabular}{|c|c|c|c|c|c|c|c|c|}
\hline & \multicolumn{6}{|c|}{ Expenditure elasticities } & \multicolumn{2}{|c|}{ Own-price elasticities } \\
\hline & \multicolumn{3}{|c|}{ Rural } & \multicolumn{3}{|c|}{ Urban } & \multirow{2}{*}{$\begin{array}{l}\text { Rural } \\
\text { Mean }\end{array}$} & \multirow{2}{*}{$\begin{array}{l}\text { Urban } \\
\text { Mean }\end{array}$} \\
\hline & Mean & Poorest & Richest & Mean & Poorest & Richest & & \\
\hline Animal products & 0.864 & 0.877 & 0.839 & 1.274 & 1.540 & 0.913 & & \\
\hline Eggs & 0.866 & 0.876 & 0.846 & 1.258 & 1.508 & 0.936 & -0.751 & -0.387 \\
\hline Fish & 0.863 & 0.877 & 0.838 & 0.567 & 1.312 & -0.166 & -0.886 & -0.507 \\
\hline Red meat & 0.865 & 0.878 & 0.841 & 1.377 & 1.623 & 1.006 & -0.587 & -0.710 \\
\hline White meat & 0.862 & 0.875 & 0.837 & 1.501 & 1.576 & 1.169 & -0.553 & -0.584 \\
\hline $\begin{array}{l}\text { Milk \& dairy } \\
\text { products }\end{array}$ & 0.870 & 0.877 & 0.849 & 1.514 & 1.580 & 1.079 & -0.746 & -0.551 \\
\hline Meal complements & 1.415 & 1.575 & 1.330 & 0.501 & 0.192 & 0.568 & & \\
\hline Fat \& oil & 1.069 & 1.382 & 0.934 & 0.692 & 0.237 & 0.916 & -0.720 & -0.175 \\
\hline Sugar \& sweets & 2.205 & 2.114 & 2.350 & 0.335 & 0.195 & -0.020 & -1.280 & -0.081 \\
\hline Condiments & -2.489 & 0.401 & -6.431 & -2.184 & -0.233 & -3.779 & 1.295 & -0.578 \\
\hline Beverages & 2.125 & 1.811 & 2.237 & 0.937 & 0.333 & 0.907 & -0.774 & -0.912 \\
\hline
\end{tabular}

Source: Compiled by authors.

Tables 4 and 5 show the nutrient elasticities for rural and urban households, respectively. For most nutrients, especially in rural areas, expenditure elasticities are relatively high — consistent with those for food demand. Unsurprisingly, high expenditure elasticities for foods and staple foods in particular entail high calorie elasticities. Since the poorest households in rural areas are lacking sufficient income to afford more calorie-dense cereals, they rely on cheaper roots and tubers - especially cassava - as the main calorie sources. ${ }^{11}$ This is also the reason the calorie elasticity of the poorest quintile is below the mean calorie elasticity in rural areas (Table 4). Moreover, due to the high share of maize in rural diets, calorie consumption is closely associated with the availability of protein, iron, and zinc, which are all contained in maize. Most of the vitamins also show high expenditure elasticities in rural areas, which is partly due to the role of vegetables but also of noncereal staples. For instance, orange-fleshed sweetpotatoes contain provitamin A. The relatively low income inequality among rural households in Malawi is also reflected in similar nutrient-income relationships between relatively poorer and richer households.

Table 4. Nutrient elasticities with respect to household expenditure and food prices in rural areas

\begin{tabular}{lccccccccc}
\hline & Calories & Protein & Iron & Zinc & Vit. A & Ribofl. & Folate & Vit. B12 & Vit. C \\
\cline { 2 - 10 } Expenditure elasticities & & & & & & & & & \\
Population mean & 0.919 & 0.920 & 0.909 & 0.909 & 0.822 & 0.926 & 0.901 & 0.876 & 0.354 \\
$\begin{array}{l}\text { Poorest quintile } \\
\text { Richest quintile }\end{array}$ & 0.894 & 0.927 & 0.919 & 0.925 & 0.863 & 0.940 & 0.874 & 0.882 & 0.306 \\
\hline Price elasticities at population mean & 0.907 & 0.874 & 0.849 & 0.850 & 0.773 & 0.874 & 0.891 & 0.856 & 0.394 \\
Maize & -0.620 & -0.453 & -0.618 & -0.601 & -0.003 & -0.634 & -0.276 & 0.006 & -0.299 \\
Rice & 0.004 & 0.034 & 0.038 & 0.041 & 0.007 & 0.057 & -0.001 & 0.000 & -0.320 \\
Other cereals & -0.010 & -0.004 & 0.005 & 0.007 & -0.006 & 0.017 & -0.005 & -0.001 & -0.091 \\
\hline
\end{tabular}

\footnotetext{
${ }^{11}$ Marshallian cross-price elasticities (not reported) suggest that rising maize prices are associated with increases in the demand for cassava only among poor and middle-income households in rural areas. The demand for cassava among rich, rural households and urban households decreases with rising maize prices. This suggests that, if the maize price rises, poor, rural households substitute cassava with maize, whereas richer and urban households partly compensate the maize price rise by a reduced cassava consumption so that the consumption of maize maintains high.
} 
Table 4. Continued

\begin{tabular}{|c|c|c|c|c|c|c|c|c|c|}
\hline & Calories & Protein & Iron & Zinc & Vit. A & Ribofl. & Folate & Vit.B12 & Vit. C \\
\hline \multicolumn{10}{|c|}{ Price elasticities at population mean } \\
\hline Cassava & -0.004 & -0.012 & -0.008 & -0.017 & -0.037 & -0.020 & 0.002 & 0.001 & 0.140 \\
\hline Potatoes & -0.023 & -0.012 & -0.015 & -0.015 & -0.070 & -0.007 & -0.017 & 0.000 & -0.114 \\
\hline Regular beans & -0.033 & -0.080 & -0.084 & -0.060 & 0.003 & -0.028 & -0.183 & 0.001 & -0.006 \\
\hline Peas \& soybeans & -0.033 & -0.078 & -0.053 & -0.062 & -0.003 & -0.046 & -0.171 & 0.000 & -0.015 \\
\hline Groundnuts & -0.040 & -0.070 & -0.043 & -0.056 & 0.001 & -0.022 & -0.088 & 0.000 & -0.003 \\
\hline Tomato & 0.005 & 0.001 & 0.000 & 0.002 & -0.052 & 0.000 & -0.001 & 0.001 & 0.010 \\
\hline Pumpkin & 0.002 & 0.000 & 0.000 & -0.003 & -0.123 & 0.004 & -0.003 & 0.000 & 0.035 \\
\hline Green leafy veg. & 0.000 & -0.005 & -0.012 & 0.000 & -0.529 & -0.025 & -0.103 & 0.002 & -0.202 \\
\hline Other vegetables & 0.000 & -0.002 & -0.004 & -0.002 & -0.015 & -0.007 & -0.006 & 0.000 & -0.015 \\
\hline Bananas & -0.007 & -0.001 & -0.003 & -0.001 & -0.017 & -0.010 & -0.009 & 0.000 & -0.044 \\
\hline Fruits & -0.010 & -0.003 & -0.004 & -0.003 & -0.079 & -0.016 & -0.023 & 0.001 & -0.299 \\
\hline Eggs & -0.001 & -0.006 & -0.001 & -0.002 & -0.008 & -0.009 & -0.002 & -0.037 & 0.000 \\
\hline Fish & -0.018 & -0.121 & -0.008 & -0.027 & -0.007 & -0.027 & -0.007 & -0.794 & 0.000 \\
\hline Red meat & -0.002 & -0.010 & -0.001 & -0.007 & 0.001 & -0.002 & 0.000 & -0.049 & 0.001 \\
\hline White meat & -0.002 & -0.012 & -0.001 & -0.005 & 0.000 & -0.004 & 0.000 & -0.041 & 0.001 \\
\hline Milk \& dairy prod. & -0.001 & -0.003 & 0.000 & -0.002 & -0.002 & -0.007 & -0.001 & -0.026 & -0.001 \\
\hline Fat \& oil & -0.028 & 0.002 & 0.002 & 0.002 & 0.004 & 0.002 & 0.002 & 0.003 & 0.002 \\
\hline Sugar \& sweets & -0.028 & 0.005 & 0.005 & 0.005 & 0.009 & 0.001 & 0.004 & 0.006 & 0.006 \\
\hline Condiments & -0.026 & 0.004 & 0.006 & 0.006 & 0.010 & -0.004 & 0.000 & 0.000 & 0.005 \\
\hline Beverages & -0.007 & 0.002 & 0.002 & 0.003 & 0.006 & -0.005 & -0.002 & -0.003 & 0.000 \\
\hline
\end{tabular}

Source: Compiled by authors.

In urban areas, expenditure elasticities for all nutrients are consistently lower than in rural areas, and they vary more across nutrients and income groups (Table 5). With rising income, mean consumption of vitamin B12 increases more than that of calories, but increases in the consumption of vitamin A, folate, and vitamin $\mathrm{C}$ are relatively small. These patterns result from high expenditure elasticities for animal products in urban areas and relatively low expenditure elasticities for pulses, vegetables, and fruits. The difference in expenditure elasticities between the poorest and richest quintile in urban areas is particularly high for nutrients that are largely obtained from animal products, such as vitamin B12, and low for those obtained from vegetables and fruits, such as vitamin A, vitamin C, and folate.

Table 5. Nutrient elasticities with respect to household expenditure and food prices in urban areas

\begin{tabular}{lccccccccc}
\hline & Calories & Protein & Iron & Zinc & Vit. A & Ribofl. & Folate & Vit. B12 & Vit. C \\
\cline { 2 - 8 } Expenditure elasticities & & & & & & & & \\
Population mean & 0.662 & 0.684 & 0.563 & 0.671 & 0.394 & 0.680 & 0.431 & 0.802 & 0.352 \\
$\begin{array}{l}\text { Poorest quintile } \\
\text { Richest quintile }\end{array}$ & 0.787 & 0.903 & 0.801 & 0.856 & 0.307 & 0.827 & 0.580 & 1.332 & 0.360 \\
Price elasticities at population mean & 0.440 & 0.377 & 0.211 & 0.400 & 0.377 & 0.466 & 0.181 & 0.378 & 0.340 \\
Maize & -0.344 & -0.288 & -0.418 & -0.412 & 0.182 & -0.441 & -0.030 & -0.188 & 0.228 \\
Rice & -0.022 & -0.011 & 0.028 & -0.004 & 0.071 & 0.007 & 0.045 & -0.037 & 0.061 \\
Other cereals & 0.007 & -0.009 & 0.071 & 0.036 & 0.042 & 0.037 & 0.050 & -0.072 & 0.042 \\
\hline
\end{tabular}


Table 5. Continued

\begin{tabular}{|c|c|c|c|c|c|c|c|c|c|}
\hline & Calories & Protein & Iron & Zinc & Vit. A & Ribofl. & Folate & Vit. B12 & Vit. C \\
\hline \multicolumn{10}{|c|}{ Price elasticities at population mean } \\
\hline Cassava & -0.040 & -0.017 & -0.051 & -0.038 & 0.021 & -0.038 & -0.013 & -0.013 & -0.183 \\
\hline Potatoes & 0.009 & 0.007 & 0.036 & 0.025 & -0.116 & 0.033 & 0.007 & -0.025 & -0.097 \\
\hline Regular beans & -0.028 & -0.008 & 0.008 & -0.013 & 0.003 & 0.001 & 0.042 & 0.028 & 0.000 \\
\hline Peas \& soybeans & -0.011 & -0.020 & -0.018 & -0.019 & -0.001 & -0.012 & -0.057 & 0.004 & -0.006 \\
\hline Groundnuts & -0.019 & -0.031 & -0.043 & -0.028 & 0.001 & -0.013 & -0.097 & 0.011 & -0.006 \\
\hline Tomato & 0.014 & 0.011 & 0.012 & 0.014 & 0.010 & 0.004 & 0.038 & -0.007 & -0.008 \\
\hline Pumpkin & -0.003 & -0.002 & -0.005 & -0.003 & -0.176 & -0.010 & -0.039 & -0.001 & -0.109 \\
\hline Green leafy veg. & 0.005 & 0.000 & -0.006 & 0.005 & -0.471 & -0.025 & -0.103 & -0.005 & -0.217 \\
\hline Other vegetables & 0.001 & 0.001 & -0.001 & 0.000 & -0.006 & -0.007 & -0.002 & -0.003 & -0.077 \\
\hline Bananas & -0.002 & 0.002 & 0.002 & 0.001 & 0.059 & -0.004 & 0.011 & -0.001 & -0.024 \\
\hline Fruits & -0.002 & -0.001 & -0.003 & -0.001 & -0.098 & -0.013 & -0.029 & -0.002 & -0.133 \\
\hline Eggs & -0.006 & -0.013 & -0.004 & -0.016 & -0.021 & -0.036 & 0.004 & -0.055 & 0.003 \\
\hline Fish & -0.022 & -0.120 & -0.014 & -0.040 & -0.013 & -0.052 & 0.016 & -0.429 & 0.013 \\
\hline Red meat & -0.010 & -0.024 & -0.008 & -0.032 & 0.003 & -0.014 & 0.013 & -0.076 & 0.009 \\
\hline White meat & -0.007 & -0.037 & -0.004 & -0.010 & 0.007 & -0.007 & 0.009 & -0.094 & 0.004 \\
\hline Milk \& dairy prod. & -0.002 & 0.005 & -0.001 & -0.004 & -0.024 & -0.034 & 0.001 & 0.005 & 0.000 \\
\hline Fat $\&$ oil & -0.079 & -0.042 & -0.066 & -0.052 & -0.012 & -0.038 & -0.073 & 0.028 & -0.014 \\
\hline Sugar \& sweets & -0.090 & -0.039 & -0.027 & -0.043 & -0.004 & -0.037 & -0.061 & 0.025 & -0.028 \\
\hline Condiments & -0.032 & -0.012 & -0.019 & -0.016 & -0.002 & -0.003 & -0.018 & 0.011 & 0.018 \\
\hline Beverages & -0.017 & -0.028 & -0.042 & -0.032 & -0.009 & -0.034 & -0.053 & 0.014 & -0.045 \\
\hline
\end{tabular}

Source: Compiled by authors.

\section{Discussion of Price Elasticities}

Marshallian own-price elasticities of food demand are shown in the right-hand part of Table 3. Overall, the values imply a high price responsiveness of households in rural and urban areas of Malawi. Apart from cassava and condiments (mainly salt) in rural areas, and regular beans in urban areas, all own-price elasticities are negative, as expected. Some food demands are even highly own-price elastic, such as sugar and sweets in rural and potatoes and tomatoes in urban areas.

In contrast, nutrient-price elasticities, which are shown in the lower parts of tables 4 and 5, are low for most food items. They indicate that nutrient consumption is price inelastic in general. Hence, households are mostly able to adjust their consumption patterns through substitution of high-priced foods, so that the effects of moderate short-term food price variations on nutritional status are relatively small. However, there are important exceptions, including the price of green leafy vegetables, fish, and maize in particular. Consumption of vitamins $\mathrm{A}$ and $\mathrm{C}$ is highly responsive to price changes of green leafy vegetables, and the consumption of vitamin B12 to fish price changes; since these foods contribute the vast share of the total amount consumed of the respective nutrient, substitution is more difficult. Resulting from the essential role of maize in local diets, the largest nutritional effects occur for maize price changes. In rural Malawi, decreasing maize prices are associated with increases in the consumption of almost all nutrients except for vitamin B12, where consumption decreases, and vitamin A, where hardly any effect occurs. In urban areas, maize price decreases result in higher calorie, protein, iron, zinc, riboflavin, and vitamin B12 consumption, but in lower consumption of vitamins A and C. 


\section{POLICY SIMULATIONS}

To analyze nutritional impacts of income-related and staple price-regulating policies and shocks, we use the estimated nutrient elasticities to simulate four scenarios. More specifically, we use per capita nutrient consumption data and the expenditure and maize price elasticities for rural and urban households estimated at income quintile means to assess how the total average nutrient consumption and the prevalence of nutritional deficiencies change, if per capita income (expenditure) of all households and the maize price increase and decrease by 20 percent. We assume that all other factors stay constant. Such ceteris paribus simulations are useful, for instance, to study impacts of a cash transfer program or a maize price subsidy for consumers. They are less suitable for assessing impacts of simultaneous price surges for multiple food items. Simulation results are reported in Table $6 .^{12}$

Scenario 1 considers an income increase of 20 percent that would notably improve the nutritional status. The prevalence of calorie deficiency would drop by about 12 percentage points to 23 percent, and iron and zinc deficiencies would fall by about 12 to 13 percentage points. The reduction in deficiencies of vitamins $\mathrm{A}, \mathrm{B} 12$, and $\mathrm{C}$ is much smaller but still notable, varying between 2 to 6 percentage points. Scenario 2 considers a 20 percent decrease in per capita incomes with opposite effects, that is, a drastic increase in nutritional deficiencies. Average total calorie consumption would fall significantly below recommendations, just exceeding requirement levels. For iron, zinc, and vitamin A, average consumption would even drop below requirement levels.

The other two scenarios shown in Table 6 consider maize price changes, namely, a price increase (scenario 3) and a price decrease (scenario 4) by 20 percent. The estimates show that nutritional effects of maize price changes are ambiguous. A 20 percent price decrease leads to increases in average consumption of calories, iron, zinc, and riboflavin of about 6 percent, whereas average consumption levels for vitamins A and B12 stay constant, with a negative tendency for vitamin A. Accordingly, the prevalence of calorie, iron, zinc, and riboflavin deficiency would decline by 4 to 5 percentage points, and virtually no or little reduction in vitamin $\mathrm{A}$, folate, vitamin B12, and vitamin $\mathrm{C}$ deficiency would be achieved. Thus, it becomes evident that a maize price subsidy would reduce protein-energy malnutrition and mineral deficiencies countrywide, yet without positive spillover effects for some of the vitamin deficiencies. In urban areas, vitamin $\mathrm{A}$ and $\mathrm{C}$ deficiencies would even increase by 2 percent and 11 percent with a 20 percent decrease in maize prices. This confirms our hypothesis that income transfers have more positive overall nutrition impacts than price subsidies for staple foods, because distortions in relative prices and crowding out effects can be avoided.

\footnotetext{
${ }^{12}$ Depending on the concrete policy, maize price changes may influence not only consumption decisions, but also production decisions and profits by farm households. We do not model such production effects explicitly. However, since the household data include own-produced foods, and we differentiate between rural and urban households in estimation, some of these effects are implicitly captured. Modeling them more comprehensively would require a farm-household approach, which is beyond the scope of this article.
} 
Table 6. Simulation results for household income and maize price changes by 20 percent

\begin{tabular}{|c|c|c|c|c|c|c|c|c|c|}
\hline & $\begin{array}{c}\text { Calories } \\
\text { (kcal) }\end{array}$ & $\begin{array}{c}\text { Protein } \\
\text { (g) }\end{array}$ & $\begin{array}{l}\text { Iron } \\
(m g)\end{array}$ & $\begin{array}{l}\text { Zinc } \\
(m g)\end{array}$ & $\begin{array}{l}\text { Vit. } A^{a} \\
(\mu g R E)\end{array}$ & $\begin{array}{c}\text { Ribo- } \\
\text { flavin } \\
(m g)\end{array}$ & $\begin{array}{l}\text { Folate }^{\mathrm{b}} \\
(\mu g \mathrm{DFE})\end{array}$ & $\begin{array}{l}\text { Vit. } \\
\text { B12 } \\
(\mu g)\end{array}$ & $\begin{array}{l}\text { Vit. C } \\
\text { (mg) }\end{array}$ \\
\hline \multicolumn{10}{|l|}{ Status quo } \\
\hline Mean consumption & 2171 & 61.97 & 18.96 & 10.17 & 392.8 & 1.068 & 384.3 & 0.906 & 76.99 \\
\hline Prevalence of deficiency (\%) & 34.8 & 12.4 & 47.1 & 54.5 & 65.6 & 32.8 & 37.3 & 84.1 & 33.8 \\
\hline \multicolumn{10}{|l|}{ Scenario 1: Income increase } \\
\hline Mean consumption & 2551 & 72.92 & 22.25 & 11.95 & 453.1 & 1.258 & 449.3 & 1.059 & 82.27 \\
\hline Prevalence of deficiency (\%) & 23.1 & 7.1 & 34.3 & 41.1 & 59.9 & 21.5 & 27.5 & 81.7 & 31.4 \\
\hline \multicolumn{10}{|l|}{ Scenario 2: Income decrease } \\
\hline Mean consumption & 1791 & 51.02 & 15.67 & 8.38 & 332.5 & 0.878 & 319.3 & 0.753 & 71.71 \\
\hline Prevalence of deficiency (\%) & 51.6 & 22.7 & 64.0 & 70.5 & 72.0 & 50.8 & 49.4 & 86.7 & 36.8 \\
\hline \multicolumn{10}{|c|}{ Scenario 3: Maize price increase } \\
\hline Mean consumption & 1918 & 56.62 & 16.68 & 8.98 & 394.2 & 0.937 & 365.2 & 0.901 & 73.32 \\
\hline Prevalence of deficiency (\%) & 45.7 & 16.9 & 58.6 & 65.2 & 65.5 & 44.9 & 40.5 & 84.2 & 35.4 \\
\hline \multicolumn{10}{|c|}{ Scenario 4: Maize price decrease } \\
\hline Mean consumption & 2298 & 64.64 & 20.10 & 10.76 & 392.1 & 1.133 & 393.8 & 0.908 & 78.83 \\
\hline Prevalence of deficiency (\%) & 30.2 & 10.7 & 42.4 & 49.6 & 65.6 & 28.2 & 35.7 & 84.0 & 33.3 \\
\hline
\end{tabular}

Source: Compiled by authors.

Notes: Nutrient consumption is reported per capita and day.

${ }^{\mathrm{a}} \mathrm{RE}=$ retinol equivalences.

${ }^{\mathrm{b}} \mathrm{DFE}=$ dietary folate equivalences. 


\section{DISCUSSION AND CONCLUSION}

In this article, we have developed an approach that is useful to analyze nutritional impacts of price- and income-related policies and shocks, going beyond calories and explicitly accounting for micronutrient deficiencies. This approach was used empirically, building on comprehensive household survey data from Malawi. The analysis has shown that malnutrition is a major problem in Malawi. Diets are dominated by staple foods, primarily maize. More than one-third of the population is not able to meet its calorie requirements. In addition, poorly diversified diets increase the risk of multiple micronutrient deficiencies. From a public health perspective, the prevalence of deficiency is particularly critical for iron, zinc, vitamin A, and vitamin B12. Correlation analysis suggests that higher household incomes and lower maize prices are associated with a more diversified diet in terms of the number of different food items consumed. However, results from the more sophisticated econometric models demonstrate that simple correlation analysis is not sufficient to project nutritional impacts of policies.

The elasticity estimates show that food demand in rural areas is highly income-responsive for the main food groups with little variation, but it varies strongly across food groups in urban areas. Among urban households, rising incomes lead to remarkable increases in demand for staples and animal products, but to only relatively small increases in demand for pulses, vegetables, and fruits. As a result, urban income growth is associated with clear improvements in the overall nutrition situation, except for vitamins A and C. Price elasticities are high for food demand but generally low for nutrient consumption. This is due to important substitution effects, which can help reduce the nutritional impacts of moderate price changes. An exception is maize, where substitution seems to be more difficult. Our simulations show that a maize price decrease would result in consumption increases for calories, iron, zinc, and riboflavin, but not for vitamins $\mathrm{A}$ and $\mathrm{C}$. In urban areas, consumption of these vitamins would even decrease. Countrywide, a 20 percent maize price reduction would reduce the prevalence of calorie, mineral, and riboflavin deficiency by 4 to 5 percent, whereas no notable effect would occur for deficiencies in vitamins A, B12, and C.

Even though the general findings are robust, a few words of caution are in order when interpreting the exact numerical results. Precise assessment of nutritional status is difficult based on household-level cross-section consumption data, but the approach used here is already a notable improvement over studies that build on national food balance sheets. In terms of nutrient-expenditure elasticities, our estimates are higher than most estimates for other poor countries. Using household data from Tanzania, Abdulai and Aubert (2004a) reported lower expenditure elasticities for calories (0.43), protein (0.44), iron (0.31), zinc (0.47), and vitamin A (0.39), but a higher expenditure elasticity for vitamin B12 (1.26). For calories, Bouis and Haddad (1992) compared estimates from different developing countries and showed that expenditure elasticities are higher when estimated indirectly from food demand elasticities than when estimated directly through single-equation models. For instance, Strauss (1984) found calorie-expenditure elasticities of around 0.85 for rural Sierra Leone with little variation across expenditure groups, using a joint production-demand model that incorporates an aggregated quadratic expenditure system. This is similar to the range of values estimated here for Malawi. As pointed out, no comparable estimates based on complete demand systems are available for micronutrients in a developing-country context. We have tried to minimize potential biases, especially related to aggregation, through various methodological details, such as estimating highly disaggregated demand systems for rural and urban households separately, calculating elasticities for expenditure quintiles, and considering the composition of food groups in deriving nutrient elasticities.

A usual concern of nutrient consumption models is endogeneity that can lead to upwardly biased estimates. Potential endogeneity arises from the link between nutrition (and health) and individual work productivity, reflected in income earnings (Strauss and Thomas 1998). The "efficiency-wage hypothesis" has been mainly discussed in the context of agricultural workers (Leibenstein 1957; Bliss and Stern 1978) but refers similarly to self-employed farmers and other persons drawing their livelihood from physical labor. However, all economic models based on conventional household survey data fall short of 
accurately accounting for this problem, because data on individual physiological nutrition and health status are lacking. Although this is also true in our case, an endogeneity bias is expected to be small. The reason is that - in economies dominated by smallholder farmers and rainfed agriculture such as Malawithe profitability of farming activities depends on a variety of factors other than nutrition.

Keeping the limitations in mind, our analysis still provides important policy lessons. Many developing-country governments use consumer price or production input subsidies on staple foods to promote food security and nutrition. Our results suggest that such policies are not always suitable to improve overall nutrition and can have undesirable side effects as a result of household dietary adjustments. Therefore, the instrument of food price regulation should be administered only with great care. In some cases, price subsidies for staples may even worsen micronutrient supply of particular population groups, as we found for vitamins $\mathrm{A}$ and $\mathrm{C}$ in urban areas of Malawi. Our findings support the general consensus that food price regulations in Sub-Saharan Africa have not been economically effective and that they can even be counterproductive in the long run (Bates 1981; Lipton 1977). ${ }^{13}$

Income-related policies are not only less market distorting but also better suited than price policies to reduce dietary deficiencies across the whole range of nutrients. In addition, income growth facilitates access to health and education services, which may contribute to reduced secondary malnutrition and higher nutrition and health awareness (Anand and Ravallion 1993). Hence, in addition to policies that directly promote economic efficiency, cash transfer and employment-generating programs can be associated with important positive growth externalities. Proper targeting can further improve nutritional outcomes, as past studies have shown (for example, Kennedy and Alderman 1987). For some micronutrients - especially vitamin A for which income elasticities are low in some areas - more direct nutrition interventions will be required. Apart from food supplementation and industrial fortification, staple food biofortification may be an interesting option (Qaim, Stein, and Meenakshi 2007). In Malawi, this includes the promotion of yellow maize and orange-fleshed sweetpotatoes. Given limited nutritional knowledge, special education campaigns would also deserve greater attention.

Considering that food insecurity and malnutrition remain huge problems in the developing world, it is surprising that economists have made little recent effort to understand and quantify nutritional impacts of policies and exogenous shocks. Whereas calorie effects are relatively well documented, aspects of micronutrient consumption have been analyzed much less. We have developed an approach that is suitable for empirical analysis, but certainly the research direction would benefit from additional work. Apart from further improvements in terms of methodology and data, a useful extension would be to go beyond consumption and quantify health outcomes associated with nutritional deficiencies.

\footnotetext{
${ }^{13}$ This does not preclude that targeted price subsidies may be a useful instrument in some cases on a temporary basis.
} 


\section{APPENDIX: SUPPLEMENTARY TABLES}

Table A.1. Summary statistics of income- and price-related variables in the demand models for rural households

\begin{tabular}{|c|c|c|c|c|c|c|}
\hline \multirow[b]{3}{*}{ FOOD } & \multicolumn{2}{|c|}{$\begin{array}{c}\text { Budget } \\
\text { share (w) }\end{array}$} & \multicolumn{2}{|c|}{$\begin{array}{c}\text { Expenditure (m) } \\
\text { per capita \& day in } \\
\text { MK }\end{array}$} & \multicolumn{2}{|c|}{$\begin{array}{c}\text { Price (p) } \\
\text { in MK/kg }\end{array}$} \\
\hline & Mean & Std. Dev. & Mean & Std. Dev. & Mean & Std. Dev. \\
\hline & 0.761 & 0.140 & 27.14 & 42.47 & 23.33 & 6.35 \\
\hline Staple foods & 0.469 & 0.167 & 16.83 & 35.77 & 14.93 & 3.38 \\
\hline Maize & 0.743 & 0.258 & & & 15.61 & 2.40 \\
\hline Rice & 0.042 & 0.108 & & & 55.82 & 7.72 \\
\hline Other cereals & 0.090 & 0.171 & & & 9.66 & 2.36 \\
\hline Cassava & 0.073 & 0.147 & & & 8.06 & 1.36 \\
\hline Potatoes & 0.051 & 0.092 & & & 9.21 & 2.05 \\
\hline Pulses & 0.103 & 0.091 & 3.59 & 4.18 & 37.02 & 5.65 \\
\hline Phaseolus beans & 0.342 & 0.398 & & & 39.03 & 5.78 \\
\hline Peas \& soybean & 0.221 & 0.351 & & & 35.53 & 6.02 \\
\hline Groundnuts & 0.271 & 0.360 & & & 37.03 & 6.08 \\
\hline Vegetables \& fruits & 0.155 & 0.097 & 5.08 & 5.61 & 27.49 & 10.72 \\
\hline Tomato & 0.210 & 0.200 & & & 34.17 & 8.27 \\
\hline Pumpkin & 0.090 & 0.185 & & & 17.92 & 6.55 \\
\hline Green leafy vegetables & 0.411 & 0.263 & & & 33.06 & 10.60 \\
\hline Other vegetables & 0.095 & 0.141 & & & 55.67 & 11.61 \\
\hline Bananas & 0.064 & 0.121 & & & 14.91 & 2.85 \\
\hline Fruits & 0.123 & 0.189 & & & 8.03 & 1.52 \\
\hline Animal products & 0.141 & 0.133 & 7.40 & $\mathbf{2 7 . 5 0}$ & 69.81 & 31.45 \\
\hline Eggs & 0.069 & 0.181 & & & 167.94 & 23.52 \\
\hline Fish & 0.487 & 0.434 & & & 48.50 & 11.04 \\
\hline Red meat & 0.097 & 0.235 & & & 135.36 & 18.32 \\
\hline White meat & 0.133 & 0.283 & & & 72.31 & 16.33 \\
\hline Milk \& dairy products & 0.028 & 0.115 & & & 38.46 & 12.12 \\
\hline Meal complements & 0.132 & 0.108 & 6.03 & 11.94 & 37.76 & 17.05 \\
\hline Fat \& oil & 0.129 & 0.194 & & & 7.82 & 2.13 \\
\hline Sugar \& sweets & 0.324 & 0.299 & & & 67.14 & 6.09 \\
\hline Condiments & 0.327 & 0.359 & & & 17.83 & 3.59 \\
\hline Beverages & 0.211 & 0.293 & & & 50.42 & 22.68 \\
\hline
\end{tabular}

Source: Compiled by authors.

Note: ${ }^{\text {a }}$ Budget shares of the food subgroups do not add up to one due to zero observations. 
Table A.2. Summary statistics of income- and price-related variables in the demand models for urban households

\begin{tabular}{|c|c|c|c|c|c|c|}
\hline \multirow[b]{3}{*}{ FOOD } & \multicolumn{2}{|c|}{$\begin{array}{c}\text { Budget } \\
\text { share }(\mathbf{w})^{\mathrm{a}}\end{array}$} & \multicolumn{2}{|c|}{$\begin{array}{l}\text { Expenditure (m) } \\
\text { per capita \& day in } \\
\text { MK }\end{array}$} & \multicolumn{2}{|c|}{$\begin{array}{c}\text { Price (p) } \\
\text { in MK/kg }\end{array}$} \\
\hline & Mean & Std. Dev. & Mean & Std. Dev. & Mean & Std. Dev. \\
\hline & 0.597 & 0.166 & 52.39 & 42.93 & 23.33 & 6.35 \\
\hline Staple foods & 0.374 & 0.136 & 38.27 & 75.83 & 14.93 & 3.38 \\
\hline Maize & 0.565 & 0.239 & & & 15.61 & 2.40 \\
\hline Rice & 0.111 & 0.129 & & & 55.82 & 7.72 \\
\hline Other cereals & 0.210 & 0.178 & & & 9.66 & 2.36 \\
\hline Cassava & 0.041 & 0.071 & & & 8.06 & 1.36 \\
\hline Potatoes & 0.073 & 0.093 & & & 9.21 & 2.05 \\
\hline Pulses & 0.066 & 0.061 & 5.48 & 11.06 & 37.02 & 5.65 \\
\hline Phaseolus beans & 0.568 & 0.400 & & & 39.03 & 5.78 \\
\hline Peas \& soybean & 0.084 & 0.213 & & & 35.53 & 6.02 \\
\hline Groundnuts & 0.224 & 0.317 & & & 37.03 & 6.08 \\
\hline Vegetables \& fruits & 0.136 & 0.075 & 13.02 & 19.39 & 27.49 & 10.72 \\
\hline Tomato & 0.376 & 0.197 & & & 34.17 & 8.27 \\
\hline Pumpkin & 0.038 & 0.102 & & & 17.92 & 6.55 \\
\hline Green leafy vegetables & 0.272 & 0.178 & & & 33.06 & 10.60 \\
\hline Other vegetables & 0.141 & 0.120 & & & 55.67 & 11.61 \\
\hline Bananas & 0.067 & 0.104 & & & 14.91 & 2.85 \\
\hline Fruits & 0.108 & 0.144 & & & 8.03 & 1.52 \\
\hline Animal products & 0.224 & 0.134 & 36.94 & 104.22 & 69.81 & 31.45 \\
\hline Eggs & 0.129 & 0.186 & & & 167.94 & 23.52 \\
\hline Fish & 0.410 & 0.354 & & & 48.50 & 11.04 \\
\hline Red meat & 0.193 & 0.257 & & & 135.36 & 18.32 \\
\hline White meat & 0.127 & 0.221 & & & 72.31 & 16.33 \\
\hline Milk \& dairy products & 0.079 & 0.157 & & & 38.46 & 12.12 \\
\hline Meal complements & 0.201 & 0.102 & 29.03 & 66.86 & 37.76 & 17.05 \\
\hline Fat \& oil & 0.337 & 0.212 & & & 7.82 & 2.13 \\
\hline Sugar \& sweets & 0.333 & 0.211 & & & 67.14 & 6.09 \\
\hline Condiments & 0.120 & 0.188 & & & 17.83 & 3.59 \\
\hline Beverages & 0.211 & 0.234 & & & 50.42 & 22.68 \\
\hline
\end{tabular}

Source: Compiled by authors.

Note: ${ }^{\text {a }}$ Budget shares of the food subgroups do not add up to one due to zero observations. 
Table A.3. Estimation results of the Working-Leser models for rural and urban households

\begin{tabular}{|c|c|c|c|c|}
\hline & \multicolumn{2}{|c|}{ Rural } & \multicolumn{2}{|c|}{ Urban } \\
\hline & Coef. & Rob. SE & Coef. & Rob. SE \\
\hline Weighted average food price, $p(\mathrm{MK} / \mathrm{kg})$ & 0.045 & 0.007 & 0.118 & 0.021 \\
\hline Total household expenditure per capita and day, $m$ (MK) & -0.082 & 0.004 & -0.133 & 0.007 \\
\hline Household size (heads) & -0.046 & 0.003 & -0.060 & 0.008 \\
\hline Gender of household head $(0=$ male, $1=$ female $)$ & 0.025 & 0.003 & 0.002 & 0.012 \\
\hline Age of household head (years) & 0.032 & 0.004 & 0.033 & 0.013 \\
\hline Primary education $(0=\text { no, } 1=\text { yes })^{\mathrm{a}}$ & -0.025 & 0.005 & -0.025 & 0.011 \\
\hline Secondary or higher education $(0=\mathrm{no}, 1=\mathrm{yes})^{\mathrm{a}}$ & -0.042 & 0.005 & -0.048 & 0.010 \\
\hline Distance to the nearest daily market $(\mathrm{km})$ & 0.008 & 0.001 & 0.014 & 0.005 \\
\hline Constant & 1.150 & 0.038 & 1.580 & 0.105 \\
\hline F-value & \multicolumn{2}{|c|}{181.19} & \multicolumn{2}{|c|}{94.40} \\
\hline R-squared & \multicolumn{2}{|c|}{0.202} & \multicolumn{2}{|c|}{0.479} \\
\hline Observations & \multicolumn{2}{|c|}{9,090} & \multicolumn{2}{|c|}{1,280} \\
\hline
\end{tabular}

Source: Compiled by authors.

Notes:The dependent variable is food budget share $(w)$. All continuous variables enter the models in logarithmic terms.

${ }^{a}$ The reference variable is no educational level completed. 
Table A.4. Estimation results of the QUAIDS models at the second and third budgeting stage for rural household

\begin{tabular}{|c|c|c|c|c|c|c|c|c|c|c|c|c|c|}
\hline \multicolumn{2}{|c|}{$\begin{array}{l}\text { Model / } \\
\text { Budgeting stage }\end{array}$} & \multicolumn{2}{|c|}{$\begin{array}{l}\text { QUAIDS 2: } \\
\text { Food }\end{array}$} & \multicolumn{2}{|c|}{$\begin{array}{c}\text { QUAIDS 3-1: } \\
\text { Staple } \\
\text { foods } \\
\end{array}$} & \multicolumn{2}{|c|}{$\begin{array}{l}\text { QUAIDS 3-2: } \\
\text { Pulses }\end{array}$} & \multicolumn{2}{|c|}{$\begin{array}{c}\text { QUAIDS 3-3: } \\
\text { Vegetables \& } \\
\text { fruits }\end{array}$} & \multicolumn{2}{|c|}{$\begin{array}{c}\text { QUAIDS 3-4: } \\
\text { Animal } \\
\text { products } \\
\end{array}$} & \multicolumn{2}{|c|}{$\begin{array}{l}\text { QUAIDS 3-5: } \\
\text { Meal } \\
\text { complements }\end{array}$} \\
\hline Variable & Para. & Coef. & Rob. SE & Coef. & Rob. SE & Coef. & Rob. SE & Coef. & Rob. SE & Coef. & Rob. SE & Coef. & Rob. SE \\
\hline \multirow[t]{6}{*}{ Constant } & $\alpha_{1}$ & 1.105 & 0.063 & 0.504 & 0.065 & -2.411 & 0.080 & -0.846 & 0.093 & 0.125 & 0.035 & 0.778 & 0.070 \\
\hline & $\alpha_{2}$ & -0.002 & 0.005 & -0.289 & 0.043 & 1.266 & 0.073 & -0.966 & 0.118 & 0.950 & 0.001 & -1.091 & 0.069 \\
\hline & $\alpha_{3}$ & 0.020 & 0.074 & -0.026 & 0.021 & 0.192 & 0.090 & 0.638 & 0.053 & -0.074 & 0.020 & 0.779 & 0.029 \\
\hline & $\alpha_{4}$ & 0.011 & 0.004 & -1.337 & 0.149 & & & -0.198 & 0.087 & -0.087 & 0.019 & -0.104 & 0.076 \\
\hline & $\alpha_{5}$ & -0.131 & 0.050 & 0.267 & 0.035 & & & 0.737 & 0.167 & 0.038 & 0.017 & & \\
\hline & $\alpha_{6}$ & -0.012 & 0.005 & 0.046 & 0.014 & & & 1.403 & 0.126 & & & & \\
\hline \multirow[t]{21}{*}{ Prices } & $\gamma_{11}$ & 0.000 & 0.000 & 0.039 & 0.012 & -1.275 & 0.099 & -0.104 & 0.023 & -0.001 & 0.001 & 0.778 & 0.070 \\
\hline & $\gamma_{12}$ & 0.004 & 0.004 & 0.012 & 0.004 & 0.972 & 0.072 & -0.119 & 0.017 & 0.000 & 0.000 & -1.091 & 0.069 \\
\hline & $\gamma_{13}$ & -0.001 & 0.000 & -0.098 & 0.030 & 0.306 & 0.060 & 0.043 & 0.011 & 0.003 & 0.001 & 0.779 & 0.029 \\
\hline & $\gamma_{14}$ & 0.009 & 0.003 & 0.024 & 0.009 & & & -0.031 & 0.011 & -0.002 & 0.001 & -0.104 & 0.076 \\
\hline & $\gamma_{15}$ & 0.000 & 0.000 & -0.010 & 0.006 & & & 0.070 & 0.021 & -0.001 & 0.001 & & \\
\hline & $\gamma_{16}$ & & & & & & & 0.112 & 0.023 & & & & \\
\hline & $\gamma_{22}$ & 0.000 & 0.000 & -0.010 & 0.006 & -0.799 & 0.068 & -0.123 & 0.025 & 0.000 & 0.000 & -0.303 & 0.034 \\
\hline & $\gamma_{23}$ & 0.000 & 0.000 & 0.003 & 0.004 & -0.255 & 0.041 & 0.051 & 0.007 & 0.000 & 0.000 & 0.166 & 0.013 \\
\hline & $\gamma_{24}$ & 0.000 & 0.000 & -0.106 & 0.029 & & & -0.027 & 0.011 & 0.000 & 0.000 & -0.047 & 0.014 \\
\hline & $\gamma_{25}$ & 0.000 & 0.000 & 0.028 & 0.008 & & & 0.078 & 0.023 & 0.000 & 0.000 & & \\
\hline & $\gamma_{26}$ & & & & & & & 0.115 & 0.022 & & & & \\
\hline & $\gamma_{33}$ & -0.005 & 0.004 & 0.007 & 0.006 & -0.104 & 0.025 & -0.019 & 0.006 & -0.004 & 0.001 & -0.179 & 0.006 \\
\hline & $\gamma_{34}$ & 0.000 & 0.000 & -0.027 & 0.008 & & & 0.015 & 0.008 & 0.000 & 0.001 & 0.040 & 0.006 \\
\hline & $\gamma_{35}$ & 0.001 & 0.002 & -0.003 & 0.008 & & & -0.030 & 0.009 & 0.002 & 0.001 & & \\
\hline & $\gamma_{36}$ & & & & & & & -0.052 & 0.013 & & & & \\
\hline & $\gamma_{44}$ & 0.000 & 0.000 & 0.210 & 0.066 & & & -0.022 & 0.013 & 0.003 & 0.001 & 0.000 & 0.006 \\
\hline & $\gamma_{45}$ & 0.001 & 0.000 & -0.051 & 0.019 & & & 0.012 & 0.010 & -0.001 & 0.000 & & \\
\hline & $\gamma_{46}$ & & & & & & & 0.035 & 0.019 & & & & \\
\hline & $\gamma_{55}$ & -0.010 & 0.003 & 0.018 & 0.012 & & & -0.049 & 0.020 & 0.000 & 0.001 & & \\
\hline & $\gamma_{56}$ & & & & & & & -0.067 & 0.021 & & & & \\
\hline & $\gamma_{66}$ & & & & & & & -0.117 & 0.033 & & & & \\
\hline
\end{tabular}


Table A.4. Continued

\begin{tabular}{|c|c|c|c|c|c|c|c|c|c|c|c|c|c|}
\hline \multirow{2}{*}{\multicolumn{2}{|c|}{$\begin{array}{l}\text { Model / } \\
\text { Budgeting stage } \\
\qquad \text { Para }\end{array}$}} & \multicolumn{2}{|c|}{$\begin{array}{l}\text { QUAIDS 2: } \\
\text { Food }\end{array}$} & \multicolumn{2}{|c|}{$\begin{array}{l}\text { QUAIDS 3-1: } \\
\text { Staple } \\
\text { foods }\end{array}$} & \multicolumn{2}{|c|}{$\begin{array}{l}\text { QUAIDS 3-2: } \\
\text { Pulses }\end{array}$} & \multicolumn{2}{|c|}{$\begin{array}{l}\text { QUAIDS 3-3: } \\
\text { Vegetables \& } \\
\text { fruits }\end{array}$} & \multicolumn{2}{|c|}{$\begin{array}{c}\text { QUAIDS 3-4: } \\
\text { Animal } \\
\text { products }\end{array}$} & \multicolumn{2}{|c|}{$\begin{array}{l}\text { QUAIDS 3-5: } \\
\text { Meal } \\
\text { complements }\end{array}$} \\
\hline & & $\begin{array}{cc}\text { Coef } & \mathrm{F} \\
. & \end{array}$ & & $\begin{array}{c}\text { Coef } \\
. \\
\end{array}$ & $\begin{array}{l}\text { Rob. } \\
\text { SE }\end{array}$ & $\begin{array}{c}\text { Coef } \\
.\end{array}$ & $\begin{array}{l}\text { Rob. } \\
\text { SE }\end{array}$ & $\begin{array}{c}\text { Coef } \\
.\end{array}$ & $\begin{array}{l}\text { Rob. } \\
\text { SE }\end{array}$ & $\begin{array}{c}\text { Coef } \\
.\end{array}$ & $\begin{array}{l}\text { Rob. } \\
\text { SE }\end{array}$ & $\begin{array}{c}\text { Coef } \\
.\end{array}$ & $\begin{array}{l}\text { Rob. } \\
\text { SE }\end{array}$ \\
\hline \multirow[t]{6}{*}{ Expenditure } & $\beta_{1}$ & -0.033 & 0.018 & 0.180 & 0.027 & 0.656 & 0.026 & 0.101 & 0.022 & -0.008 & 0.005 & -0.079 & 0.011 \\
\hline & $\beta_{2}$ & 0.000 & 0.002 & 0.087 & 0.013 & -0.586 & 0.015 & 0.101 & 0.018 & 0.000 & 0.000 & 0.166 & 0.014 \\
\hline & $\beta_{3}$ & 0.025 & 0.021 & 0.043 & 0.012 & -0.179 & 0.028 & -0.044 & 0.015 & 0.007 & 0.003 & 0.016 & 0.007 \\
\hline & $\beta_{4}$ & -0.003 & 0.001 & -0.361 & 0.042 & & & 0.077 & 0.019 & 0.001 & 0.003 & -0.004 & 0.013 \\
\hline & $\beta_{5}$ & 0.010 & 0.014 & -0.004 & 0.025 & & & -0.057 & 0.034 & -0.001 & 0.003 & & \\
\hline & $\beta_{6}$ & & & & & & & -0.136 & 0.026 & & & & \\
\hline \multirow{6}{*}{$\begin{array}{l}\text { Expenditure } \\
\text {-squared }\end{array}$} & $\lambda_{1}$ & 0.000 & 0.002 & -0.045 & 0.006 & 0.656 & 0.026 & 0.000 & 0.001 & 0.000 & 0.000 & 0.001 & 0.000 \\
\hline & $\lambda_{2}$ & 0.000 & 0.000 & -0.018 & 0.005 & -0.586 & 0.015 & 0.001 & 0.001 & 0.000 & 0.000 & 0.001 & 0.001 \\
\hline & $\lambda_{3}$ & -0.001 & 0.002 & 0.019 & 0.004 & -0.179 & 0.028 & 0.000 & 0.001 & 0.000 & 0.000 & -0.012 & 0.000 \\
\hline & $\lambda_{4}$ & 0.000 & 0.000 & 0.088 & 0.013 & & & -0.005 & 0.001 & 0.000 & 0.000 & 0.005 & 0.001 \\
\hline & $\lambda_{5}$ & 0.002 & 0.001 & -0.005 & 0.012 & & & -0.001 & 0.002 & 0.000 & 0.000 & & \\
\hline & $\lambda_{6}$ & & & & & & & 0.004 & 0.002 & & & & \\
\hline \multirow{6}{*}{$\begin{array}{l}\text { Probability } \\
\text { density }\end{array}$} & $\varphi_{1}$ & 0.347 & 0.007 & 0.668 & 0.059 & 0.232 & 0.038 & 0.394 & 0.013 & -0.007 & 0.005 & 0.010 & 0.011 \\
\hline & $\varphi_{2}$ & 0.000 & 0.001 & 0.053 & 0.013 & 1.381 & 0.048 & 0.053 & 0.020 & 1.448 & 0.011 & 0.739 & 0.013 \\
\hline & $\varphi_{3}$ & 0.050 & 0.005 & 0.210 & 0.015 & 1.579 & 0.046 & 1.425 & 0.032 & -0.009 & 0.002 & 0.906 & 0.065 \\
\hline & $\varphi_{4}$ & -0.003 & 0.000 & 2.182 & 0.117 & & & 0.102 & 0.018 & 0.024 & 0.003 & 0.140 & 0.008 \\
\hline & $\varphi_{5}$ & 0.002 & 0.003 & 0.091 & 0.036 & & & 0.008 & 0.024 & -0.004 & 0.003 & & \\
\hline & $\varphi_{6}$ & & & & & & & -0.079 & 0.023 & & & & \\
\hline \multirow{6}{*}{$\begin{array}{l}\text { Uncentered } \\
\text { R-squared }\end{array}$} & $w_{l}$ & \multicolumn{2}{|l|}{0.419} & \multicolumn{2}{|l|}{0.879} & \multicolumn{2}{|l|}{0.100} & \multicolumn{2}{|l|}{0.511} & \multicolumn{2}{|l|}{-0.028} & \multicolumn{2}{|l|}{0.380} \\
\hline & $w_{2}$ & \multicolumn{2}{|l|}{0.010} & \multicolumn{2}{|l|}{0.165} & \multicolumn{2}{|l|}{0.099} & \multicolumn{2}{|l|}{-0.057} & \multicolumn{2}{|l|}{0.375} & \multicolumn{2}{|l|}{0.503} \\
\hline & $w_{3}$ & \multicolumn{2}{|l|}{0.704} & \multicolumn{2}{|l|}{0.309} & \multicolumn{2}{|l|}{0.234} & \multicolumn{2}{|l|}{0.682} & \multicolumn{2}{|l|}{0.016} & \multicolumn{2}{|l|}{0.727} \\
\hline & $w_{4}$ & -0.045 & & -0.164 & & & & 0.303 & & 0.011 & & 0.486 & \\
\hline & $w_{5}$ & 0.260 & & 0.103 & & & & 0.210 & & 0.003 & & & \\
\hline & $w_{6}$ & & & & & & & 0.314 & & & & & \\
\hline Observations & & 9,0 & & 9,0 & 88 & 7,5 & & 9,0 & & 7,42 & & 9,00 & \\
\hline
\end{tabular}

Source: Compiled by authors.

Note: Only coefficients relevant for calculating elasticities are shown for brevity. 
Table A.5. Estimation results of the QUAIDS models at the second and third budgeting stage for urban household

\begin{tabular}{|c|c|c|c|c|c|c|c|c|c|c|c|c|c|}
\hline \multicolumn{2}{|c|}{$\begin{array}{l}\text { Model / } \\
\text { Budgeting stage }\end{array}$} & \multicolumn{2}{|c|}{$\begin{array}{l}\text { QUAIDS 2: } \\
\text { Food }\end{array}$} & \multicolumn{2}{|c|}{$\begin{array}{l}\text { QUAIDS 3-1: } \\
\text { Staple } \\
\text { foods } \\
\end{array}$} & \multicolumn{2}{|c|}{$\begin{array}{l}\text { QUAIDS 3-2: } \\
\text { Pulses }\end{array}$} & \multicolumn{2}{|c|}{$\begin{array}{c}\text { QUAIDS 3-3: } \\
\text { Vegetables \& } \\
\text { fruits } \\
\end{array}$} & \multicolumn{2}{|c|}{$\begin{array}{c}\text { QUAIDS 3-4: } \\
\text { Animal } \\
\text { products } \\
\end{array}$} & \multicolumn{2}{|c|}{$\begin{array}{c}\text { QUAIDS 3-5: } \\
\text { Meal } \\
\text { complements }\end{array}$} \\
\hline Variable & Para. & Coef. & Rob. SE & Coef. & Rob. SE & Coef. & Rob. SE & Coef. & Rob. SE & Coef. & Rob. SE & Coef. & Rob. SE \\
\hline \multirow[t]{6}{*}{ Constant } & $\alpha_{1}$ & -2.019 & 0.163 & 0.805 & 0.030 & 1.206 & 0.282 & 1.024 & 0.147 & 0.420 & 0.171 & 0.852 & 0.116 \\
\hline & $\alpha_{2}$ & 0.559 & 0.135 & 0.109 & 0.057 & -2.708 & 0.412 & -0.313 & 0.162 & 0.929 & 0.032 & -0.109 & 0.181 \\
\hline & $\alpha_{3}$ & 1.141 & 0.203 & -0.390 & 0.043 & -2.360 & 0.286 & -0.313 & 0.102 & -0.489 & 0.176 & 0.926 & 0.181 \\
\hline & $\alpha_{4}$ & -0.139 & 0.133 & -0.088 & 0.104 & & & -0.313 & 0.095 & 0.066 & 0.148 & -0.726 & 0.064 \\
\hline & $\alpha_{5}$ & 1.324 & 0.208 & -0.046 & 0.054 & & & -0.313 & 0.119 & -0.402 & 0.166 & & \\
\hline & $\alpha_{6}$ & & & & & & & -0.313 & 0.184 & & & & \\
\hline \multirow[t]{21}{*}{ Prices } & $\gamma_{11}$ & -0.976 & 0.120 & -0.035 & 0.006 & 0.851 & 0.116 & -0.313 & 0.052 & 0.077 & 0.026 & -0.007 & 0.160 \\
\hline & $\gamma_{12}$ & 0.183 & 0.056 & -0.010 & 0.006 & -0.131 & 0.098 & -0.313 & 0.034 & -0.052 & 0.011 & 0.327 & 0.245 \\
\hline & $\gamma_{13}$ & 0.324 & 0.085 & 0.039 & 0.007 & -0.523 & 0.065 & -0.313 & 0.049 & -0.020 & 0.020 & -0.382 & 0.144 \\
\hline & $\gamma_{14}$ & 0.012 & 0.050 & -0.004 & 0.007 & & & -0.313 & 0.045 & 0.017 & 0.012 & 0.067 & 0.064 \\
\hline & $\gamma_{15}$ & 0.435 & 0.080 & 0.020 & 0.006 & & & -0.313 & 0.029 & -0.054 & 0.026 & & \\
\hline & $\gamma_{16}$ & & & & & & & -0.313 & 0.039 & & & & \\
\hline & $\gamma_{22}$ & -0.023 & 0.023 & -0.025 & 0.013 & -0.106 & 0.146 & -0.313 & 0.020 & -0.067 & 0.006 & -0.883 & 0.358 \\
\hline & $\gamma_{23}$ & -0.060 & 0.021 & -0.004 & 0.009 & -0.438 & 0.096 & -0.313 & 0.029 & 0.021 & 0.009 & 0.731 & 0.173 \\
\hline & $\gamma_{24}$ & 0.006 & 0.010 & 0.007 & 0.021 & & & -0.313 & 0.034 & -0.001 & 0.009 & -0.203 & 0.080 \\
\hline & $\gamma_{25}$ & -0.101 & 0.025 & 0.035 & 0.014 & & & -0.313 & 0.014 & 0.025 & 0.009 & & \\
\hline & $\gamma_{26}$ & & & & & & & -0.313 & 0.016 & & & & \\
\hline & $\gamma_{33}$ & -0.105 & 0.048 & -0.053 & 0.011 & 0.354 & 0.091 & -0.313 & 0.083 & -0.031 & 0.034 & -0.612 & 0.073 \\
\hline & $\gamma_{34}$ & 0.007 & 0.016 & 0.038 & 0.016 & & & -0.313 & 0.057 & 0.004 & 0.014 & 0.253 & 0.051 \\
\hline & $\gamma_{35}$ & -0.153 & 0.032 & -0.036 & 0.008 & & & -0.313 & 0.038 & -0.015 & 0.019 & & \\
\hline & $\gamma_{36}$ & & & & & & & -0.313 & 0.060 & & & & \\
\hline & $\gamma_{44}$ & -0.018 & 0.008 & -0.054 & 0.043 & & & -0.313 & 0.048 & 0.027 & 0.009 & -0.106 & 0.033 \\
\hline & $\gamma_{45}$ & -0.007 & 0.022 & 0.014 & 0.013 & & & -0.313 & 0.028 & -0.009 & 0.014 & & \\
\hline & $\gamma_{46}$ & & & & & & & -0.313 & 0.048 & & & & \\
\hline & $\gamma_{55}$ & -0.159 & 0.067 & -0.037 & 0.017 & & & -0.313 & 0.024 & 0.014 & 0.032 & & \\
\hline & $\gamma_{56}$ & & & & & & & -0.313 & 0.025 & & & & \\
\hline & $\gamma_{66}$ & & & & & & & -0.313 & 0.031 & & & & \\
\hline
\end{tabular}


Table A.5. Continued

\begin{tabular}{|c|c|c|c|c|c|c|c|c|c|c|c|c|c|}
\hline \multirow{2}{*}{\multicolumn{2}{|c|}{$\begin{array}{l}\text { Model / } \\
\text { Budgeting stage } \\
\\
\text { Variable } \quad \text { Para } \\
\end{array}$}} & \multicolumn{2}{|c|}{$\begin{array}{l}\text { QUAIDS 2: } \\
\text { Food }\end{array}$} & \multicolumn{2}{|c|}{$\begin{array}{l}\text { QUAIDS 3-1: } \\
\text { Staple } \\
\text { foods }\end{array}$} & \multicolumn{2}{|c|}{$\begin{array}{l}\text { QUAIDS 3-2: } \\
\text { Pulses }\end{array}$} & \multicolumn{2}{|c|}{$\begin{array}{l}\text { QUAIDS 3-3: } \\
\text { Vegetables \& } \\
\text { fruits }\end{array}$} & \multicolumn{2}{|c|}{$\begin{array}{c}\text { QUAIDS 3-4: } \\
\text { Animal } \\
\text { products }\end{array}$} & \multicolumn{2}{|c|}{$\begin{array}{l}\text { QUAIDS 3-5: } \\
\text { Meal } \\
\text { complements }\end{array}$} \\
\hline & & $\begin{array}{cc}\text { Coef } & \mathrm{R} \\
\cdot & \mathrm{S} \\
\end{array}$ & & $\begin{array}{c}\text { Coef } \\
.\end{array}$ & & $\begin{array}{c}\text { Coef } \\
.\end{array}$ & $\begin{array}{l}\text { Rob. } \\
\text { SE }\end{array}$ & $\begin{array}{c}\text { Coef } \\
.\end{array}$ & $\begin{array}{l}\text { Rob. } \\
\text { SE }\end{array}$ & $\begin{array}{c}\text { Coef } \\
.\end{array}$ & $\begin{array}{l}\text { Rob. } \\
\text { SE }\end{array}$ & $\begin{array}{c}\text { Coef } \\
. \\
\end{array}$ & $\begin{array}{l}\text { Rob. } \\
\text { SE }\end{array}$ \\
\hline \multirow[t]{6}{*}{ Expenditure } & $\beta_{1}$ & 0.587 & 0.034 & -0.031 & 0.022 & 0.182 & 0.021 & 0.096 & 0.041 & -0.042 & 0.032 & -0.192 & 0.077 \\
\hline & $\beta_{2}$ & -0.103 & 0.027 & 0.082 & 0.025 & -0.213 & 0.074 & 0.023 & 0.039 & 0.003 & 0.008 & 0.421 & 0.075 \\
\hline & $\beta_{3}$ & -0.170 & 0.040 & 0.145 & 0.016 & 1.007 & 0.065 & -0.307 & 0.036 & 0.116 & 0.033 & -0.310 & 0.025 \\
\hline & $\beta_{4}$ & -0.029 & 0.028 & -0.208 & 0.038 & & & 0.174 & 0.038 & -0.042 & 0.027 & 0.081 & 0.035 \\
\hline & $\beta_{5}$ & -0.269 & 0.040 & 0.024 & 0.020 & & & -0.054 & 0.038 & 0.112 & 0.029 & & \\
\hline & $\beta_{6}$ & & & & & & & 0.004 & 0.067 & & & & \\
\hline Expenditure & $\lambda_{1}$ & -0.026 & 0.002 & -0.010 & 0.003 & 0.000 & 0.000 & -0.017 & 0.006 & 0.002 & 0.001 & 0.030 & 0.010 \\
\hline \multirow[t]{5}{*}{-squared } & $\lambda_{2}$ & 0.003 & 0.001 & -0.010 & 0.004 & -0.002 & 0.001 & 0.011 & 0.005 & -0.008 & 0.001 & -0.047 & 0.011 \\
\hline & $\lambda_{3}$ & 0.005 & 0.002 & -0.006 & 0.003 & 0.001 & 0.000 & 0.034 & 0.006 & -0.004 & 0.002 & 0.015 & 0.003 \\
\hline & $\lambda_{4}$ & 0.007 & 0.001 & 0.023 & 0.007 & & & -0.024 & 0.006 & 0.006 & 0.001 & 0.002 & 0.003 \\
\hline & $\lambda_{5}$ & 0.011 & 0.002 & 0.001 & 0.003 & & & 0.005 & 0.005 & -0.004 & 0.001 & & \\
\hline & $\lambda_{6}$ & & & & & & & 0.001 & 0.008 & & & & \\
\hline \multirow{6}{*}{$\begin{array}{l}\text { Probability } \\
\text { density }\end{array}$} & $\varphi_{1}$ & 0.188 & 0.014 & 0.524 & 0.027 & 0.552 & 0.028 & 0.454 & 0.041 & 0.249 & 0.039 & -0.087 & 0.032 \\
\hline & $\varphi_{2}$ & 0.162 & 0.013 & 0.075 & 0.012 & 0.707 & 0.250 & 0.295 & 0.051 & 1.265 & 0.038 & 0.480 & 0.046 \\
\hline & $\varphi_{3}$ & 0.437 & 0.050 & 0.207 & 0.013 & 9.022 & 0.408 & 0.251 & 0.016 & 0.176 & 0.020 & -0.018 & 0.055 \\
\hline & $\varphi_{4}$ & 0.046 & 0.008 & 1.064 & 0.114 & & & 0.109 & 0.021 & 0.048 & 0.013 & 0.104 & 0.007 \\
\hline & $\varphi_{5}$ & 0.560 & 0.061 & 0.195 & 0.026 & & & 0.058 & 0.028 & 0.028 & 0.023 & & \\
\hline & $\varphi_{6}$ & & & & & & & -0.077 & 0.052 & & & & \\
\hline \multirow{6}{*}{$\begin{array}{l}\text { Uncentered } \\
\text { R-squared }\end{array}$} & $w_{1}$ & \multicolumn{2}{|l|}{0.849} & \multicolumn{2}{|l|}{0.867} & \multicolumn{2}{|l|}{0.694} & \multicolumn{2}{|l|}{0.802} & \multicolumn{2}{|l|}{0.364} & \multicolumn{2}{|l|}{0.640} \\
\hline & $w_{2}$ & \multicolumn{2}{|l|}{0.578} & \multicolumn{2}{|l|}{0.454} & \multicolumn{2}{|l|}{0.140} & \multicolumn{2}{|l|}{0.137} & \multicolumn{2}{|l|}{0.462} & \multicolumn{2}{|l|}{0.787} \\
\hline & $w_{3}$ & \multicolumn{2}{|l|}{0.798} & \multicolumn{2}{|l|}{0.639} & \multicolumn{2}{|l|}{0.123} & \multicolumn{2}{|l|}{0.727} & \multicolumn{2}{|l|}{0.220} & \multicolumn{2}{|l|}{0.180} \\
\hline & $w_{4}$ & 0.819 & & 0.180 & & & & 0.525 & & 0.230 & & 0.571 & \\
\hline & $w_{5}$ & 0.759 & & 0.393 & & & & 0.321 & & 0.262 & & & \\
\hline & $w_{6}$ & & & & & & & 0.384 & & & & & \\
\hline Observations & & 1,2 & & 1,2 & & 1, & & & 266 & 1,2 & & 1,2 & \\
\hline
\end{tabular}

Source: Compiled by authors.
Note: Only coefficients relevant for calculating elasticities are shown for brevity. 


\section{REFERENCES}

Abdulai, A., and D. Aubert. 2004a. A cross-section analysis of household demand for food and nutrients in Tanzania. Agricultural Economics 31 (1): 67-79.

.2004b. Nonparametric and parametric analysis of calorie consumption in Tanzania. Food Policy 29 (2): $113-129$.

Alfonzo, L., and H. H. Peterson. 2006. Estimating food demand in Paraguay from household survey data. Agricultural Economics 34 (3): 243-257.

Anand, S., and M. Ravallion. 1993. Human development in poor countries: On the role of private incomes and public services. Journal of Economic Perspective 7 (1): 133-150.

Asche, F., and C. R. Wessells. 1997. On price indices in the almost ideal demand system. American Journal of Agricultural Economics 79 (4): 1182-1185.

Banks, J., R. Blundell, and A. Lewbel. 1997. Quadratic Engel curves and consumer demand. Review of Economics and Statistics 124 (4): 527-539.

Bates, R. H. 1981. Markets and states in tropical Africa: The political basis of agricultural policies. Berkley, Calif., U.S.A.: University of California Press.

Behrman, J. R., and A. B. Deolalikar. 1987. Will developing country nutrition improve with income? A case study for rural South India. Journal of Political Economy 95 (3): 492-507.

Behrman, J. R., and B. L. Wolfe. 1984. More evidence on nutrition demand: Income seems overrated and women's schooling underemphasized. Journal of Development Economics 14 (1): 105-128.

Bliss, C., and N. Stern. 1978. Productivity, wages, and nutrition. Part I: The theory. Journal of Development Economics 5 (4): 331-362.

Bouis, H. E. 1994. The effect of income on demand for food in poor countries: Are our food consumption databases giving us reliable estimates? Journal of Development Economics 44 (1): 199-226.

Bouis, H. E., and L. J. Haddad. 1992. Are estimates of calorie-income elasticities too high? A recalibration of the plausible range. Journal of Development Economics 39 (2): 333-364.

Bouis, H., L. Haddad, and E. Kennedy. 1992. Does it matter how we survey demand for food? Evidence from Kenya and the Philippines. Food Policy 17 (5): 349-360.

Brinkman, H.-J., S. de Pee, I. Sanogo, L. Subran, and M. W. Bloem. 2009. High food prices and the global financial crisis have reduced access to nutritious food and worsened nutritional status and health. Journal of Nutrition 140 (1): 153S-161S.

Deaton, A. 1988. Quality, quantity, and spatial variation of price. American Economic Review 78 (3): 418-430.

Denning, G., P. Kabambe, P. Sanchez, A. Malik, R. Flor, R. Harawa, P. Nkhoma, C. Zamba, C. Banda, C. Magombo, M. Kaeting, J. Wangila, and J. Sachs. 2009. Input subsidies to improve smallholder maize productivity in Malawi: Toward an African Green Revolution. PLoS Biol 7 (1): e1000023. doi: 10.1371/journal.pbio.1000023.

Edgerton, D. L. 1997. Weak separability and the estimation of elasticities in multistage demand systems. American Journal of Agricultural Economics 79 (1): 62-79.

FAO (Food and Agriculture Organization of the United Nations). 2010. World Food Dietary Assessment System, version 2.0. International Network of Food Data Systems of the Food and Agricultural Organization of the United Nations. http://www.fao.org/infoods/software_worldfood_en.stm. Accessed in June 2010.

FAO/WFP (FAO/World Food Programme). 2009. The state of food insecurity in the world: Economic crisesimpacts and lessons learned. Rome: FAO.

FAO/WHO/UNU (FAO/World Health Organization/United Nations University). 1985. Energy and protein requirements. Report of a joint $\mathrm{FAO} / \mathrm{WHO} / \mathrm{UNU}$ expert consultation. WHO Technical Report 724. Geneva: WHO. 
FAO/WHO/UNU. 2001. Human energy requirements. Report of a joint FAO/WHO/UNU expert consultation. FAO Food and Nutrition Technical Report 1. Rome: FAO.

Gao, X. M., E. J. Wailes, and G. L. Cramer. 1996. A two-stage rural household demand analysis: Microdata evidence from Jiangsu province, China. American Journal of Agricultural Economics 78 (3): 604-613.

Gibson, R. S. 2005. Principles of nutritional assessment. 2nd ed. New York: Oxford University Press.

Haddad, L., and R. Kanbur. 1990. How serious is the neglect of intra-household inequality? Economic Journal 100 (402): 866-881.

Harrigan, J. 2003. U-turns and full circles: Two decades of agricultural reform in Malawi 1981-2000. World Development 31 (5): 847-863.

2008. Food insecurity, poverty, and the Malawian Starter Pack: Fresh start or false start? Food Policy 33 (3): 237-249.

Heckman, J. J. 1979. Sample selection bias as a specification error. Econometrica 47 (1): 153-162.

Heien, D., and C. R. Wessells. 1990. Demand systems estimation with microdata: A censored regression approach. Journal of Business and Economic Statistics 8 (3): 365-371.

Horton, S., \& J. Ross. 2003. The economics of iron deficiency. Food Policy 28 (1): 51-75.

Huang, K. S. 1996. Nutrient elasticities in a complete food demand system. American Journal of Agricultural Economics 78 (1): 21-29.

IZiNCG (International Zinc Nutrition Consultative Group). 2004. Assessment of the risk of zinc deficiency in populations and options for its control. Technical Document 1. Ed. C. Hotz and K. H. Brown. Food and Nutrition Bulletin 25 (1, s2): S91-S203.

Jiang, B., and J. Davis. 2007. Household food demand in rural China. Applied Economics 39 (3): 373-380.

Kennedy, E. T., and H. H. Alderman. 1987. Comparative analyses of nutritional effectiveness of food subsidies and other food-related interventions. Washington, D.C.: International Food Policy Research Institute.

Lancaster, K. J. 1971. Consumer theory: A new approach. New York: Columbia University Press.

Leibenstein, H. 1957. The theory of underemployment in backward economies. Journal of Political Economy 65 (2): 91-103.

Leser, C. E. V. 1963. Forms of Engel functions. Econometrica 31 (4): 694-703.

Lipton, M. 1977. Why poor people stay poor: A study of urban bias in world development. London: Temple Smith.

Mason, J., J. Rivers, and C. Helwig. 2005. Recent trends in malnutrition in developing regions: Vitamin A deficiency, anemia, iodine deficiency, and child underweight. Food and Nutrition Bulletin 26 (1): 57-162.

Micronutrient Initiative/Flour Fortification Initiative/USAID/GAIN/WHO/World Bank/UNICEF (Micronutrient Initiative/Flour Fortification Initiative/United States Agency for International Development/Global Alliance for Improved Nutrition/World Health Organization/World Bank/United Nations Children's Fund) 2009. Investing in the future: A united call for action on vitamin and mineral deficiencies. Ottawa: Micronutrient Initiative.

NSO (National Statistical Office). 2005. Malawi Second Integrated Household Survey (IHS-2) 2004-2005: Basic information document. Zomba, Malawi: NSO.

NSO/ORC Macro. 2005. Malawi Demographic and Health Survey 2004. Zomba, Malawi, and Calverton, Maryland, U.S.A.: NSO and ORC Macro.

Pelletier, D. L., J. W. Low, and L. A. H. Msukwa. 1991. Malawi maternal and child nutrition study: Study design and anthropometric characteristics of children and adults. American Journal of Human Biology 3 (4): 347 361.

Pitt, M. M. 1983. Food preferences and nutrition in rural Bangladesh. Review of Economics and Statistics 65 (1): $105-114$.

Pollak, R. A., and T. J. Wales. 1981. Demographic variables in demand analysis. Econometrica 49 (6): 1533-1551. 
Qaim, M., A. J. Stein, and J. V. Meenakshi. 2007. Economics of biofortification. Agricultural Economics 37 (s1): 119-133.

Ramakrishnan, U. 2002. Prevalence of micronutrient malnutrition worldwide. Nutrition Reviews 60 (5): 46-52.

Ruel, M. T., N. Minot, and L. Smith. 2005. Patterns and determinants of fruit and vegetable consumption in SubSaharan Africa: A multicountry comparison. Background paper for the joint FAO/WHO workshop on fruit and vegetables for health, September 1-3, 2004, Kobe, Japan. Washington, D.C.: International Food Policy Research Institute.

Sadoulet, E., and A. de Janvry. 1995. Quantitative development policy analysis. Baltimore and London: Johns Hopkins University Press.

Sahn, D. E. 1988. The effect of price and income changes on food-energy intake in Sri Lanka. Economic Development and Cultural Change 36 (2): 315-340.

Sanghvi, T., M. van Ameringen, M. Baker, and J. Fiedler. 2007. Vitamin and mineral deficiencies technical situation analysis: A report for the Ten Year Strategy for the Reduction of Vitamin and Mineral Deficiencies. Food and Nutrition Bulletin 28 (1s): S157-S219.

Shonkwiler, J. S., and S. T. Yen. 1999. Two-step estimation of a censored system of equations. American Journal of Agricultural Economics 81 (4): 972-982.

Skoufias, E., V. Di Maro, T. Gonzalez-Cassio, and S. Rodriguez Ramirez. 2009. Nutrient consumption and household income in rural Mexico. Agricultural Economics 40 (6): 657-675.

Smith, L., H. Alderman, and D. Aduayom. 2006. Food insecurity in Sub-Saharan Africa: New estimates from household expenditure surveys. IFPRI Research Report 146. Washington, D.C.: International Food Policy Research Institute.

Strauss, J. 1984. Joint determination of food consumption and production in rural Sierra Leone: Estimates of a household-firm model. Journal of Development Economics 44 (1): 77-103.

Strauss, J., and D. Thomas. 1998. Health, nutrition, and economic development. Journal of Economic Literature 36 (2): 766-817.

Svedberg, P. 2000. Poverty and undernutrition: Theory, measurement, and policy. Oxford: Oxford University Press.

von Braun, J., H. de Haen, and J. Blanken. 1991. Commercialization of agriculture under population pressure: Effects on production, consumption, and nutrition in Rwanda. IFPRI Research Report 85. Washington, D.C.: International Food Policy Research Institute.

WHO/FAO (World Health Organization/Food and Agriculture Organization of the United Nations). 2003. Diet, nutrition, and the prevention of chronic diseases. Report of a joint WHO/FAO expert consultation. WHO Technical Report 916. Geneva: WHO.

2004. Vitamin and mineral requirements. 2nd ed. Geneva: WHO.

.2006. Guidelines on food fortification with micronutrients. Ed. L. Allen, B. de Benoist, O. Dary, and R. Hurrel. Geneva: WHO; Rome: FAO.

Working, H. 1943. Statistical laws of family expenditure. Journal of the American Statistical Association 38 (221): 43-56.

World Bank. 2006. Repositioning nutrition as central to development: A strategy for large-scale action. Directions in Development. Washington, D.C.: World Bank.

2007. Malawi poverty and vulnerability assessment: Investing in our future. Full report. Washington, D.C.: World Bank.

Yen, S. T., K. Kan, and S.-J. Su. 2002. Household demand for fats and oils: Two-step estimation of a censored demand system. Applied Economics 34 (14): 1799-1806. 




\section{RECENT IFPRI DISCUSSION PAPERS}

\section{For earlier discussion papers, please go to www.ifpri.org/pubs/pubs.htm\#dp. All discussion papers can be downloaded free of charge.}

1016. Optimal rainfall insurance contracts for maize producers in Ghana's northern region: A mathematical programming approach. Francis M. Muamba and John M. Ulimwengu, 2010.

1015. Impacts of climate change on agriculture and policy options for adaptation: The case of Vietnam. Bingxin Yu, Tingju Zhu, Clemens Breisinger, and Nguyen Manh Hai, 2010.

1014. Spatial price transmission and market integration in Senegal's groundnut market. Ousmane Badiane, John M. Ulimwengu, and Fleur Wouterse, 2010.

1013. Strategies for adapting to climate change in rural Sub-Saharan Africa: A review of data sources, poverty reduction strategy programs (PRSPS) and national adaptation plans for agriculture (NAPAs) in ASARECA member countries. Jonathan Makau Nzuma, Michael Waithaka, Richard Mbithi Mulwa, Miriam Kyotalimye, and Gerald Nelson, 2010.

1012. Do health investments improve agricultural productivity?: Lessons from agricultural household and health research. Paul E. McNamara, John M. Ulimwengu, and Kenneth L. Leonard, 2010.

1011. Investigating the role of poultry in livelihoods and the impact of avian flu on livelihoods outcomes in Africa: Evidence from Ethiopia, Ghana, Kenya, and Nigeria. Ekin Birol, Dorene Asare-Marfo, Gezahegn Ayele, Akwasi Mensa-Bonsu, Lydia Ndirangu, Benjamin Okpukpara, Devesh Roy, and Yorbol Yakhshilikov, 2010.

1010. Constraints to fertilizer use in Nigeria: Insights from agricultural extension service. Afua B. Banful, Ephraim Nkonya, and Victor Oboh, 2010.

1009. Do household definitions matter in survey design? Results from a randomized survey experiment in Mali. Lori Beaman and Andrew Dillon, 2010.

1008. Livestock development planning in Uganda: Identification of areas of opportunity and challenge. Todd Benson and Samuel Mugarura. 2010.

1007. Migratory responses to agricultural risk in northern Nigeria. Andrew Dillion, Valerie Mueller, and Sheu Salau. 2010.

1006. Do comprehensive Africa agriculture development program (CAADP) processes make a difference to country commitments to develop agriculture?: The case of Ghana. Shashidhara Kolavalli, Kathleen Flaherty, Ramatu Al-Hassan, and Kwaku Owusu Baah, 2010.

1005. The new Nicaraguan water law in context: Institutions and challenges for water management and governance. Paula Novo and Alberto Garrido, 2010.

1004. Potential of carbon markets for small farmers: A literature review. Alessandro De Pinto, Marilia Magalhaes, and Claudia Ringler, 2010.

1003. Understanding gender differences in agricultural productivity in Uganda and Nigeria. Amber Peterman, Agnes Quisumbing, Julia Behrman, and Ephraim Nkonya, 2010.

1002. Old problems in the new solutions? Politically motivated allocation of program benefits and the "new" fertilizer subsidies. Afua Branoah Banful, 2010.

1001. The role of public-private partnerships in promoting smallholder access to livestock markets in developing countries: methodology and case studies. Karl M. Rich and Clare A. Narrod, 2010.

1000. Mapping the policy process in Nigeria: Examining linkages between research and policy. Noora-Lisa Aberman, Eva Schiffer, Michael Johnson, and Victor Oboh, 2010.

999. Sales location and supply response among semisubsistence farmers in Benin: A heteroskedastic double selection model. Hiroyuki Takeshima and Alex Winter-Nelson, 2010.

998. A review of collective action in rural Ghana. Adam Salifu, Gian Nicola Francesconi, and Shashidhara Kolavalli, 2010.

997. Eight years of Doha trade talks: Where do we stand? Antoine Bouet and David Laborde Debucquet, 2010.

996. Price, inventories, and volatility in the global wheat Market. Kyösti Pietola, Xing Liu, and Miguel Robles, 2010.

995. Access, adoption, and diffusion: Understanding the long-term impacts of improved vegetable and fish technologies in Bangladesh. Neha Kumar and Agnes R. Quisumbing, 2010. 


\section{INTERNATIONAL FOOD POLICY RESEARCH INSTITUTE}

\section{www.ifpri.org}

IFPRI HEADQUARTERS

2033 K Street, NW

Washington, DC 20006-1002 USA

Tel.: +1-202-862-5600

Fax: +1-202-467-4439

Email: ifpri@cgiar.org

IFPRI ADDIS ABABA

P. O. Box 5689

Addis Ababa, Ethiopia

Tel.: +251116463215

Fax: +251116462927

Email: ifpri-addisababa@cgiar.org

IFPRI NEW DELHI

CG Block, NASC Complex, PUSA

New Delhi 110-012 India

Tel.: 9111 2584-6565

Fax: 9111 2584-8008 / 2584-6572

Email: ifpri-newdelhi@cgiar.org 